\title{
Noradrenergic Excitation and Inhibition of GABAergic Cell Types in Rat Frontal Cortex
}

\author{
Yasuo Kawaguchi and Tomomi Shindou \\ Laboratory for Neural Circuits, Bio-Mimetic Control Research Center, The Institute of Physical and Chemical Research \\ (RIKEN), Shimoshidami, Moriyama, Nagoya 463-0003, Japan
}

\begin{abstract}
Noradrenaline (NA) from the locus coeruleus and GABA from intracortical nonpyramidal cells exert strong influences on cortical activity. To assess possible interaction between the two, the effects of noradrenergic agonists on spontaneous GABAergic IPSCs as well as on the activity of identified GABAergic cell types were investigated by in vitro whole-cell recordings from the frontal cortex of 18- to 22-d-old rats. NA (3-50 $\mu \mathrm{M})$ and an $\alpha$-adrenergic agonist, 6-fluoronorepinephrine (FNE; 30-50 $\mu \mathrm{M}$ ), induced an increase of IPSC frequency in pyramidal cells, but a $\beta$-adrenergic agonist did not. This increase was reduced by tetrodotoxin, bicuculline, and $\alpha$-adrenergic antagonists, suggesting that GABAergic cells are excited via $\alpha$-adrenoceptors. Fast-spiking or late-spiking cells were depolarized by application of NA or FNE, but none demonstrated spike firings. The former morphologically included common multipolar cells with
\end{abstract}

extended axonal arborizations as well as chandelier cells, and the latter neurogliaform cells. Most somatostatinimmunoreactive regular or burst-spiking cells, including Martinotti cells and wide arbor cells, were depolarized and accompanied by spike firing. In a few cases this was preceded by hyperpolarization. Cholecystokinin-immunoreactive regular or burst-spiking nonpyramidal cells, including large basket cells, were affected heterogeneously: depolarization, hyperpolarization followed by depolarization, or hyperpolarization resulted. The findings suggest that, similar to the effects of acetylcholine, the excitability of cortical GABAergic cell types is differentially regulated by NA and that NA actions are similar to cholinergic ones in some GABAergic cell types but not in others.

Key words: noradrenaline; frontal cortex; nonpyramidal cell; cholecystokinin; somatostatin; GABA; $\alpha$-adrenoceptor
In the neocortex, noradrenaline (NA) and acetylcholine (ACh) are released, respectively, from afferent fibers originating in noradrenergic cells in the locus coeruleus and cholinergic cells in the nucleus basalis of the basal forebrain. NA and ACh may diffuse through the extracellular space and mediate their effects at sites beyond the synaptic cleft (Séguéla et al., 1990; Umbriaco et al., 1994). Both systems are suggested to be related to the control of arousal and attention (Aston-Jones et al., 1991; Foote et al., 1991; Jones, 1993). The excitation of neurons in the locus coeruleus or in the nucleus basalis is followed by electroencephalographic activation, that is, a shift from low-frequency, high-amplitude to high-frequency, low-amplitude fluctuations in the neocortex (Berridge and Foote, 1991; Metherate et al., 1992).

Application of NA usually increases the excitability of pyramidal cells, with reduction of spike frequency adaptation and slow depolarization (Haas and Konnerth, 1983; Madison and Nicoll, 1986; Foehring et al., 1989; Dodt et al., 1991; Wang and McCormick, 1993). The slow noradrenergic EPSP is induced in pyramidal cells by repetitive electrical stimulation of neocortical slices (Benardo, 1993).

\footnotetext{
Received March 3, 1998; revised June 5, 1998; accepted June 9, 1998.

This work was supported by the Frontier Research Program, RIKEN, and Grants-in-Aid for Scientific Research from the Japanese Ministry of Education, Science, Sports and Culture. The authors thank N. Wada and S. Kato for technical assistance. We are grateful to Dr. Robert Benoit for an antiserum against somatostatin 28. Antibody $28.2 \mathrm{MoAb}$ raised against gastrin/CCK was provided by CURE/UCLA/DDC Antibody/RIA Core.

Correspondence should be addressed to Dr. Yasuo Kawaguchi, Bio-Mimetic Control Research Center, RIKEN, 2271-130 Anagahora, Shimoshidami, Moriyama, Nagoya 463-0003, Japan.

Dr. Shindou's present address: Pharmaceutical Research Laboratories, Kyowa Hakko Kogyo, Sunto-gun, Shizuoka, 411-0943, Japan.

Copyright (C) 1998 Society for Neuroscience $\quad 0270-6474 / 98 / 186963-14 \$ 05.00 / 0$
}

The activity of cortical GABAergic nonpyramidal cells is also modulated by NA or adrenaline; both cause increases in the frequency of IPSPs or IPSCs in pyramidal cells of the hippocampus, piriform cortex, and somatosensory cortex (Madison and Nicoll, 1988; Doze et al., 1991; Gellman and Aghajanian, 1993; Bennett et al., 1998). This increase is mediated by a direct excitatory action on GABAergic cells via an $\alpha$-adrenoceptor (Bergles et al., 1996; Marek and Aghajanian, 1996).

Like NA, ACh also induces IPSPs or IPSCs in pyramidal cells indirectly through excitation of cortical GABAergic cells in the neocortex (McCormick and Prince, 1986; Kawaguchi, 1997) and hippocampus (Pitler and Alger, 1992; Behrends and ten Bruggencate, 1993), in addition to direct excitatory effects on pyramidal cells (for review, see Nicoll et al., 1990). Several GABAergic cell types have been identified on the basis of their firing response to a depolarizing current, axon arborization pattern, synaptic connections, and coexpression of neuroactive substances in the rat frontal cortex (Kawaguchi and Kubota, 1997, 1998). There are differences in cholinergic responses among cortical GABAergic cell types (Kawaguchi, 1997). Cholinergic or muscarinic agonists affect membrane potentials at the somata of peptide-containing GABAergic cells with regular- or burst-spiking characteristics but not GABAergic cells with fast-spiking or late-spiking characteristics. Somatostatin-immunoreactive cells are depolarized with spike firing, whereas large cholecystokinin (CCK)immunoreactive cells are hyperpolarized followed by a slow depolarization. Noradrenaline may also regulate the excitability of cortical GABAergic cell types differentially. Because noradrenergic projections from the locus coeruleus have been demonstrated in the rat frontal cortex (Morrison et al., 1978; Sakaguchi and Nakamura, 1987; Van Bockstaele et al., 1996), the effects of 


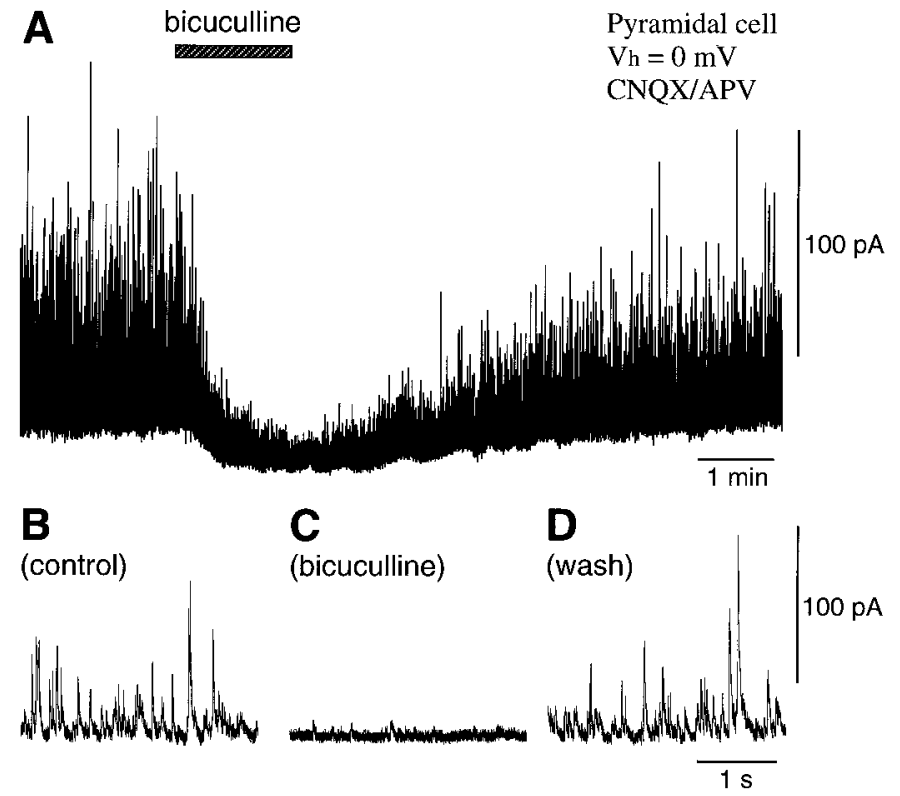

Figure 1. Spontaneous GABAergic postsynaptic currents in layer V pyramidal cells. Outward currents were recorded in pyramidal cells at a holding potential $\left(V_{\mathrm{h}}\right)$ of $0 \mathrm{mV}$ in a solution containing antagonists for non-NMDA and NMDA receptors $(20 \mu \mathrm{M} \mathrm{CNQX}$ and $50 \mu \mathrm{M}$ APV) $(A$, $B)$. These outward currents were suppressed by an antagonist for GABA ${ }_{\mathrm{A}}$ receptors $(10 \mu \mathrm{M}$ bicuculline) $(A, C)$ and recovered after washing $(A, D)$.

noradrenergic agonists on spontaneous GABAergic IPSCs as well as on the activity of identified GABAergic cell types were investigated by in vitro whole-cell recordings.

\section{MATERIALS AND METHODS}

Slice preparation and whole-cell recording. The experiments were performed on young Wistar rats (18-22 d postnatal). Animals were deeply anesthetized with ether and decapitated. The brains were quickly removed and submerged in ice-cold physiological Ringer's solution. Sections of frontal cortex (200 $\mu \mathrm{m}$ thick) were cut, immersed in a buffered solution containing (in $\mathrm{mM}$ ) $\mathrm{NaCl} 124.0, \mathrm{KCl} 3.0, \mathrm{CaCl}_{2}$ 2.4, $\mathrm{MgCl}_{2}$ 1.2, $\mathrm{NaHCO}_{3} 26.0, \mathrm{NaH}_{2} \mathrm{PO}_{4} 1.0$, glucose 10.0, and aerated with a mixture of $95 \% \mathrm{O}_{2}$ and $5 \% \mathrm{CO}_{2}$. Cells in the frontal cortex (medial agranular cortex and anterior cingulate cortex) were recorded in a whole-cell mode at $30^{\circ} \mathrm{C}$ using a $40 \times$ water immersion objective.

Voltage-clamp recordings from pyramidal cells. The electrode solution for the voltage-clamp recording consisted of (in $\mathrm{mM}$ ): cesium methanesulfonate $120, \mathrm{KCl}$ 5.0, EGTA 10.0, $\mathrm{CaCl}_{2} 1.0, \mathrm{MgCl}_{2}$ 2.0, ATP 4.0, GTP 0.3 , HEPES 8, QX314 5.0, and biocytin 20. The quaternary lidocaine derivative QX314 (Astra, Westborough, MA) was included to suppress fast sodium currents. Voltage-clamp recordings were made with an Axopatch 1D amplifier (Axon Instruments, Foster City, CA). Spontaneous postsynaptic currents were collected and analyzed using Spike 2 software (Cambridge Electronic Design, Cambridge, UK).

Current-clamp recordings from nonpyramidal cells. The electrode solution for the current-clamp recording consisted of (in $\mathrm{mM}$ ): potassium methylsulfate $115, \mathrm{KCl} 5.0$, EGTA $0.5, \mathrm{MgCl}_{2}$ 1.7, ATP 4.0, GTP 0.3, HEPES 8.5, and biocytin 17. Current-clamp recordings were made in the bridge mode with an Axoclamp-2B amplifier (Axon Instruments). Voltage responses to current pulses were collected using Axodata software (Axon Instruments) and analyzed with Axograph software (Axon Instruments). Continuous voltage signals were collected and analyzed with Spike 2 software. Resting potentials were measured just after the patched membranes were ruptured by suction. Input resistances of cells were determined by passing hyperpolarizing current pulses (duration, 500$600 \mathrm{msec}$ ), which induced voltage shifts of $6-15 \mathrm{mV}$ negative to rest. The generation of two or more spikes on slow humps from hyperpolarization (burst-spiking) was investigated by depolarizing current pulses of threshold strength from -75 to $-85 \mathrm{mV}$.
A

(a) control

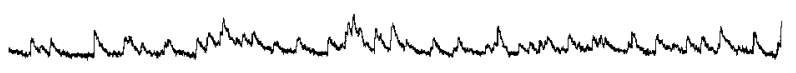

(b) NA

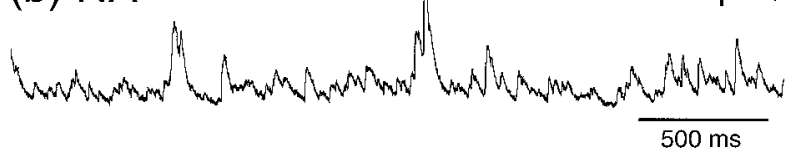

B
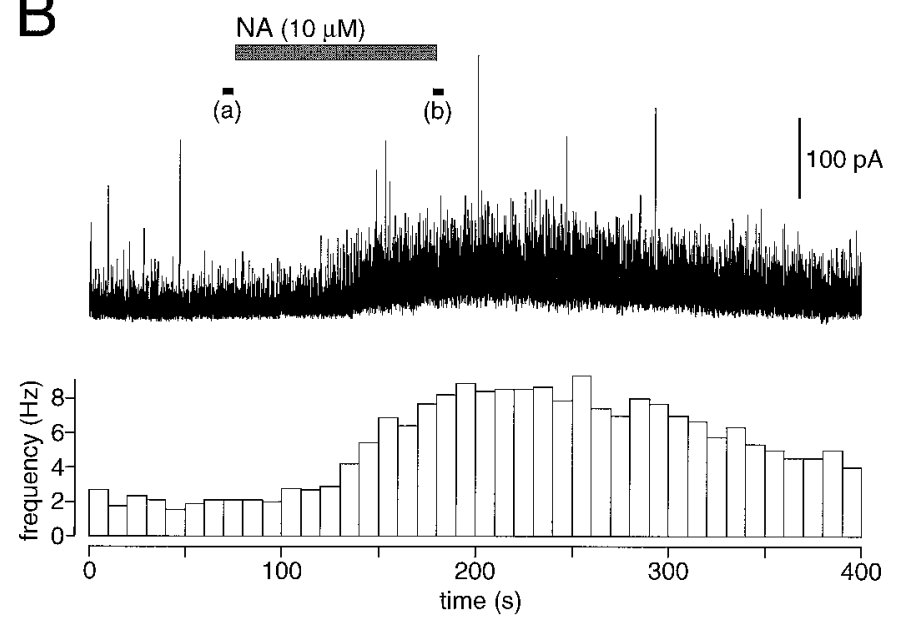

Figure 2. Noradrenaline (NA)-induced increase of spontaneous IPSCs. $A$, Spontaneous IPSCs in a layer $\mathrm{V}$ pyramidal cell under control conditions $(a)$ and in the presence of $10 \mu \mathrm{M}$ NA $(b) . B$, The amplitude and frequency of spontaneous IPSCs were increased by application of NA in a solution containing $10 \mu \mathrm{M}$ CNQX and $50 \mu \mathrm{M}$ APV (CNQX/APV). The currents at the black bars (a) and (b) are shown in $A$. Each bin in the histogram represents the frequency $(\mathrm{Hz})$ of the spontaneous IPSCs for $10 \mathrm{sec}$.

Drugs were applied by replacing the solution superfusing the slice with one containing a set concentration. D-2-amino-5-phosphonovaleric acid $(\mathrm{APV} ; 50 \mu \mathrm{M})$ and 6-cyano-7-nitroquinoxaline-2,3-dione (CNQX; 10-20 $\mu \mathrm{M})$ were obtained from Tocris (Bristol, UK); tetrodotoxin (TTX; 0.3-1 $\mu \mathrm{M})$ was from Sankyo (Tokyo, Japan); NA $(3-50 \mu \mathrm{M})$ was obtained from Wako (Osaka, Japan); (-)-isoproterenol (50-100 $\mu \mathrm{M})$ was from Aldrich (Milwaukee, WI); FNE $(10-50 \mu \mathrm{M})$ and phenylephrine $(10-100 \mu \mathrm{M})$ were from Research Biochemicals (Natick, MA); and (-)-bicuculline methiodide $(10-100 \mu \mathrm{M})$, clonidine $(100 \mu \mathrm{M})$, prazosin $(1-3 \mu \mathrm{M}),(-)$ propranolol $(30 \mu \mathrm{M})$, and yohimbine $(10 \mu \mathrm{M})$ were from Sigma (St. Louis, MO). The solution for the recording contained $50 \mu \mathrm{M}$ sodium disulfite (Kanto Chemical, Tokyo, Japan) to prevent oxidation (Gellman and Aghajanian, 1993).

Antibodies. A monoclonal antibody raised against gastrin/CCK (28.2 $\mathrm{MoAb}$ ) was provided by CURE/UCLA/DDC Antibody/RIA Core. For control it was preabsorbed with an excess $\left(10^{-6} \mathrm{M}\right)$ of sulfated CCKoctapeptide (Peptide Inst. Inc., Japan), resulting in no staining in the rat frontal cortex. A rat monoclonal antibody against somatostatin (MAB354) was purchased from Chemicon (Temecula, CA). Preabsorption with an excess $\left(10^{-6} \mathrm{M}\right)$ of somatostatin (Sigma) resulted in no staining. Rabbit antiserum against somatostatin (somatostatin 28) (S 309) was kindly donated by Dr. Robert Benoit (The Montreal General Hospital) and preabsorbed with an excess $\left(10^{-6} \mathrm{M}\right)$ of somatostatin 28 (Sigma) as a control (no immunoreactivity). A rabbit antiserum against vasoactive intestinal polypeptide (VIP) (catalog no. 20077) was obtained from Incstar (Stillwater, MN) and preabsorbed with excess $\left(10^{-5} \mathrm{M}\right)$ VIP (Sigma) as a control (no immunoreactivity). For investigation of parvalbumin, a mouse monoclonal antibody (P-3171) from Sigma and a rabbit antiserum (PV-28) from Swant (Bellinzona, Switzerland) were used. 
A
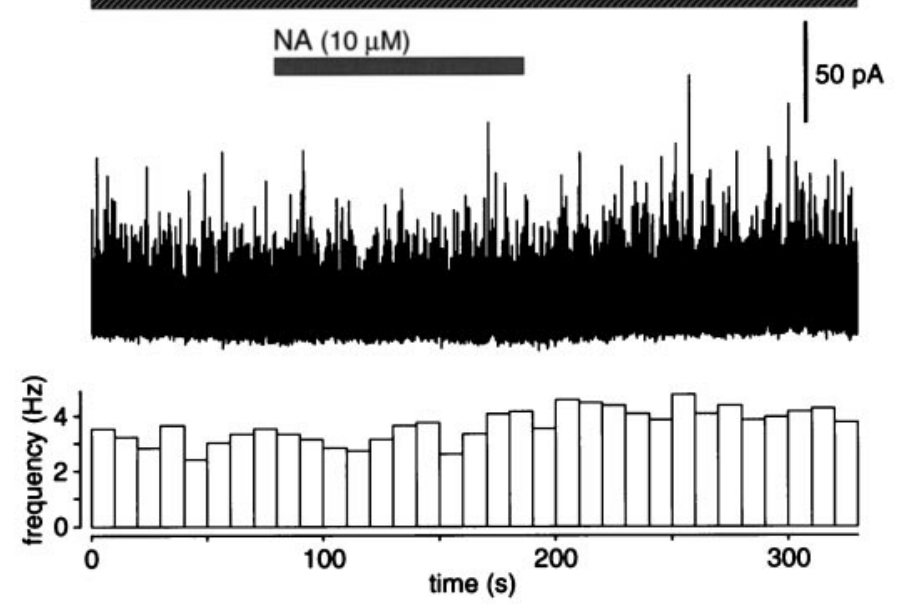

B

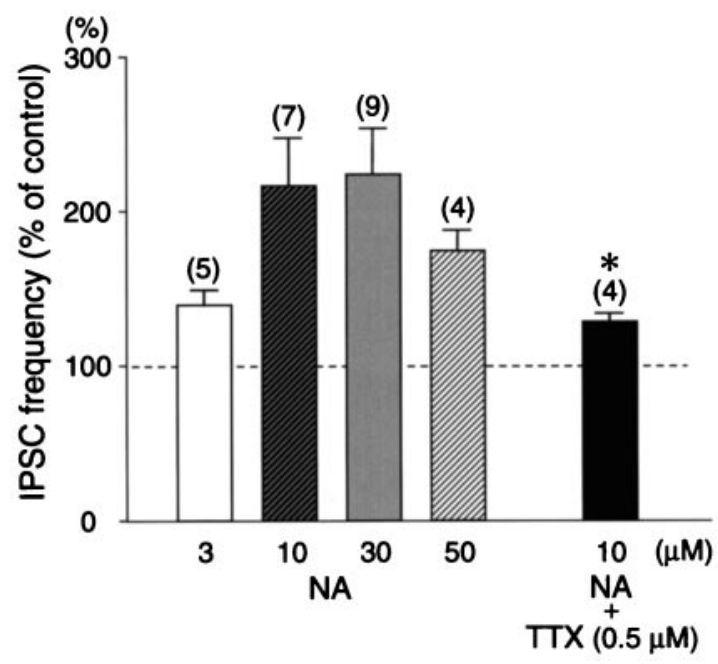

Figure 3. Reduction of NA-induced synaptic currents by tetrodotoxin (TTX). $A$, NA-induced increase of GABAergic currents was not observed in a solution containing TTX $(0.5 \mu \mathrm{M})$ and CNQX/APV. B, Dose dependency of NA (3-50 $\mu \mathrm{M})$-induced increase of IPSC frequency and its reduction by TTX. The effects of NA are normalized as a percentage of control values. The error bars represent SEM. The numbers of cells investigated are given in parentheses. The effects of NA $(10 \mu \mathrm{M})$ in the presence or absence of TTX were compared using Mann-Whitney $U$ test. ${ }^{*} p<0.05$.

It was confirmed by double immunofluorescence that the cellular distributions of neurochemical markers (parvalbumin, somatostatin, CCK, and VIP) of nonpyramidal cells in frontal cortex of 19- to 21-d-old rats were similar to those of adult rats. In the 19- to 21-d-old animal, parvalbumin-positive cells $(n=2279)$ and somatostatin-positive cells $(n=1218)$ were always singly stained with no cross-immunoreactivity. Similarly parvalbumin-positive $(n=2237)$ and CCK-positive cells $(n=$ $284)$ were clearly separable, as were parvalbumin-positive $(n=1485)$ and VIP-positive cells $(n=469)$, somatostatin-positive $(n=1642)$ and CCK-positive cells $(n=311)$, and somatostatin-positive $(n=780)$ and VIP-positive cells $(n=595)$. CCK-positive cells $(n=146$ in layers II/III, 107 in layer V, and 100 in layer VI) were sometimes positive for VIP (58\% in layers II/III, 64\% in layer V, and $40 \%$ in layer VI). Similarly VIP-positive cells $(n=412$ in layers II/III, 277 in layer V, and 205 in layer VI) were occasionally positive for CCK (21\% in layers II/III, $25 \%$ in layer $\mathrm{V}$, and $20 \%$ in layer VI). These observations were in line with the literature and thus showed these chemical markers to be distributed similarly in the frontal cortex of both 19- to 21-d-old and adult rats (Kubota et al., 1994; Kubota and Kawaguchi, 1997), with CCK and
A

(a) control

$100 \mathrm{pA}$

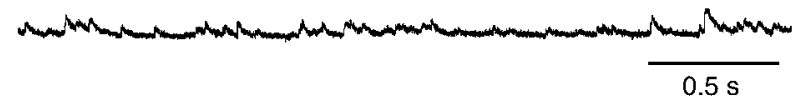

(b) FNE

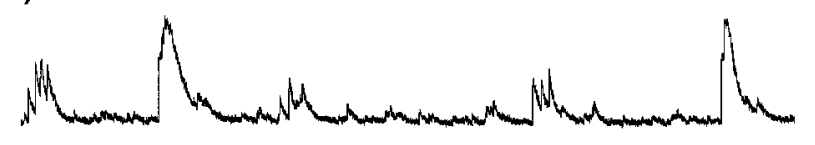

B

FNE $(50 \mu \mathrm{M})$

(a)

(b)
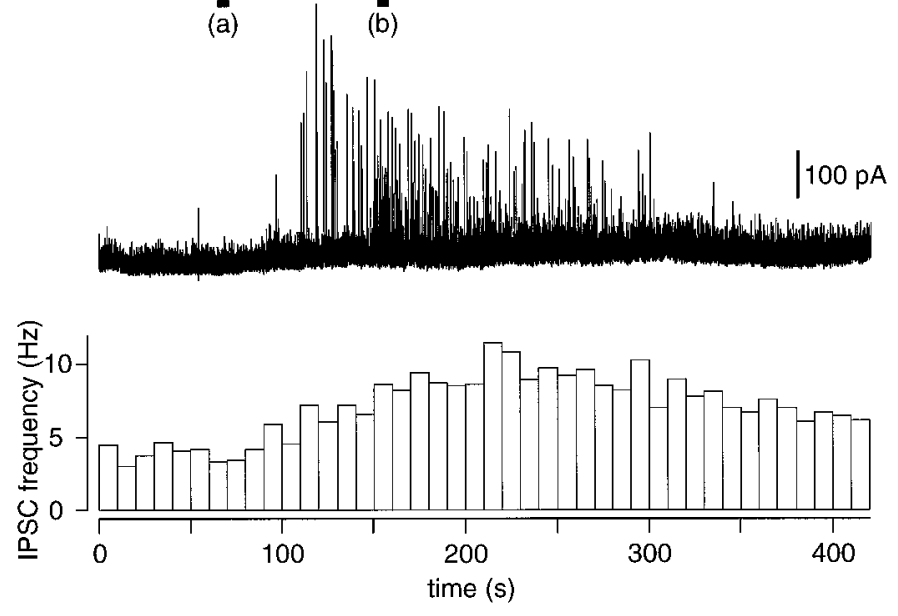

Figure 4. Increase of spontaneous IPSCs induced by an $\alpha$-adrenergic agonist, FNE. $A$, Spontaneous IPSCs in a layer $\mathrm{V}$ pyramidal cell under control conditions $(a)$ and in the presence of $50 \mu \mathrm{M}$ FNE $(b)$. FNE induced the burst of IPSCs in this cell. $B$, The amplitude and frequency of spontaneous IPSCs were increased by application of FNE in a solution containing CNQX/APV. The currents at the black bars $(a)$ and $(b)$ are shown in $A$. Each bin in the histogram represents the frequency $(\mathrm{Hz})$ of the spontaneous IPSCs for $10 \mathrm{sec}$.

somatostatin cells constituting separate populations (Somogyi et al., 1984; Demeulemeester et al., 1988; Kubota and Kawaguchi, 1997).

Histological procedures for immersion-fixed slices. Tissue slices containing biocytin-loaded cells were fixed by immersion in $4 \%$ paraformaldehyde and $0.2 \%$ picric acid in $0.1 \mathrm{M}$ sodium phosphate buffer $(\mathrm{PB}), \mathrm{pH} 7.4$, overnight at $4^{\circ} \mathrm{C}$, and incubated in PB containing $10 \%$ sucrose for $30 \mathrm{~min}$ and $20 \%$ sucrose for $1 \mathrm{hr}$. The tissue was next frozen on dry ice, thawed twice, and incubated in $\mathrm{PB}$ containing $0.5 \% \mathrm{H}_{2} \mathrm{O}_{2}$ for 30 min to suppress endogenous peroxidase activity. The slices, without resectioning, were then washed with $0.05 \mathrm{~m}$ Tris-HCl-buffered saline (TBS), $\mathrm{pH}$ 7.6, for $1 \mathrm{hr}$. Each slice was further treated by one of the following two procedures.

(1) After they were washed in TBS, some slices were incubated with avidin-biotin-peroxidase complex (1:100; Vector, Burlingame, CA) in TBS containing $0.1 \%$ Triton X-100 (TX) for $4 \mathrm{hr}$ at room temperature. After they were washed in TBS, the slices were reacted with 3,3'diaminobenzidine tetrahydrochloride (DAB) $(0.05 \%)$ and $\mathrm{H}_{2} \mathrm{O}_{2}$ $(0.003 \%)$ in Tris- $\mathrm{HCl}$ buffer.

(2) The other slices were processed for double-fluorescence immunohistochemistry. All staining procedures were performed at room temperature. The slices were incubated overnight with the mouse monoclonal antibody against gastrin/CCK (diluted 1:2000) and the rat monoclonal antibody against somatostatin (1:500) in TBS containing $2 \%$ bovine serum albumin (BSA), $10 \%$ normal goat serum (NGS), and $0.5 \%$ TX. After the slices were washed in TBS, they were incubated in a mixture of dichlorotriazinyl amino fluorescein (DTAF)-conjugated donkey anti-mouse $\operatorname{IgG}(1: 100 ; 192 \mathrm{~F}$, Chemicon) and tetramethylrhodamine isothiocyanate (TRITC)-conjugated goat anti-rat IgG (1:100; 
A

FNE $(50 \mu \mathrm{M})$

\section{$\operatorname{TTX}(1 \mu \mathrm{M})$}

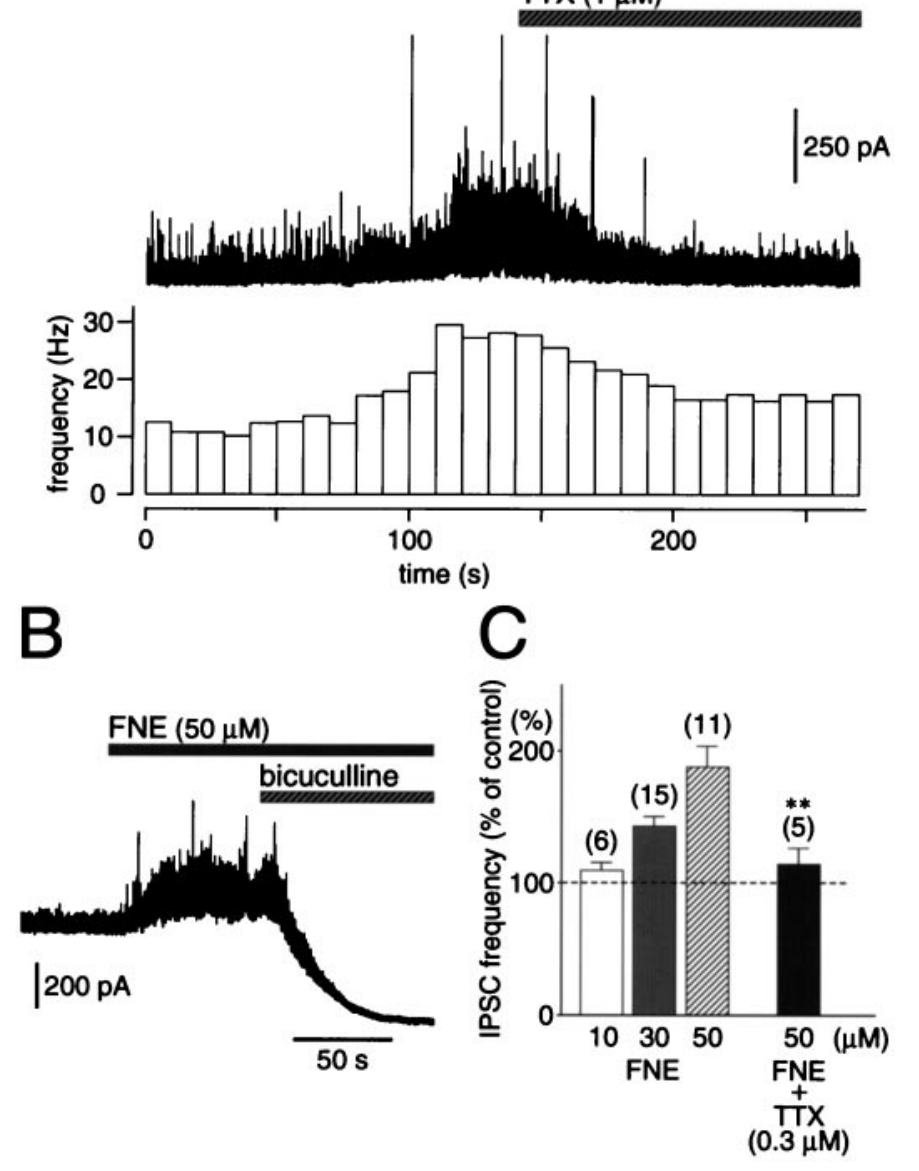

Figure 5. Reduction of FNE-induced currents by TTX and bicuculline. $A$, FNE $(50 \mu \mathrm{M})$-induced synaptic currents were reduced by TTX $(1 \mu \mathrm{M})$ application. The solution always contained CNQX/APV. B, Both spontaneously occurring and FNE $(50 \mu \mathrm{M})$-induced outward currents were completely suppressed by simultaneous application of the $\mathrm{GABA}_{\mathrm{A}}$ receptor antagonist bicuculline $(100 \mu \mathrm{M})$. The solution always contained CNQX/APV. $C$, Dose dependency of FNE (10-50 $\mu \mathrm{M})$-induced increase of IPSC frequency and its reduction by TTX. The data are percentages of the control value. The error bars represent SEM. The numbers of cells examined are given in parentheses. The effects of FNE $(50 \mu \mathrm{M})$ in the presence or absence of TTX $(0.3 \mu \mathrm{M})$ were compared using MannWhitney $U$ test. ${ }^{* *} p<0.01$.

183R, Chemicon) in TBS containing BSA, NGS, and TX for $4 \mathrm{hr}$, followed by incubation with a sulfonated derivative of 7-amino-4metylcoumarin-3-acetic acid (AMCA-S)-conjugated streptavidin (1:600; S-6364, Molecular Probes, Eugene, OR) in TBS for 2 hr. After they were washed in TBS, the sections were coverslipped in $50 \%$ glycerin in TBS, observed, and photographed with a fluorescence microscope (BX-50, Olympus) using filters (Olympus): U-MNUA $(360-370 \mathrm{~nm}$ exciter and $420-460 \mathrm{~nm}$ emitter) for AMCA-S to identify biocytin-labeled cells, U-MNIBA $(470-490 \mathrm{~nm}$ exciter and 515-550 $\mathrm{nm}$ emitter) for DTAF, and U-MWIG $(520-550 \mathrm{~nm}$ exciter and $>580$ $\mathrm{nm}$ emitter) for TRITC. Only one color was visualized with each filter combination. Cross-reactivity of the secondary antibodies was not observed. After examination for fluorescence, the slices were incubated with avidin-biotin-peroxidase complex in TBS and reacted with DAB and $\mathrm{H}_{2} \mathrm{O}_{2}$ in Tris-HCl buffer.

In both cases, the slices were washed in TBS, mounted on gelatincoated glass slides, and dried. They were then immersed in PB containing $0.1 \%$ osmium tetroxide for 10 min, dehydrated, and embedded in Epon (TAAB, Berkshire, UK). The dendrites, axonal processes, and somata of
A

prazosin $(3 \mu \mathrm{M})$
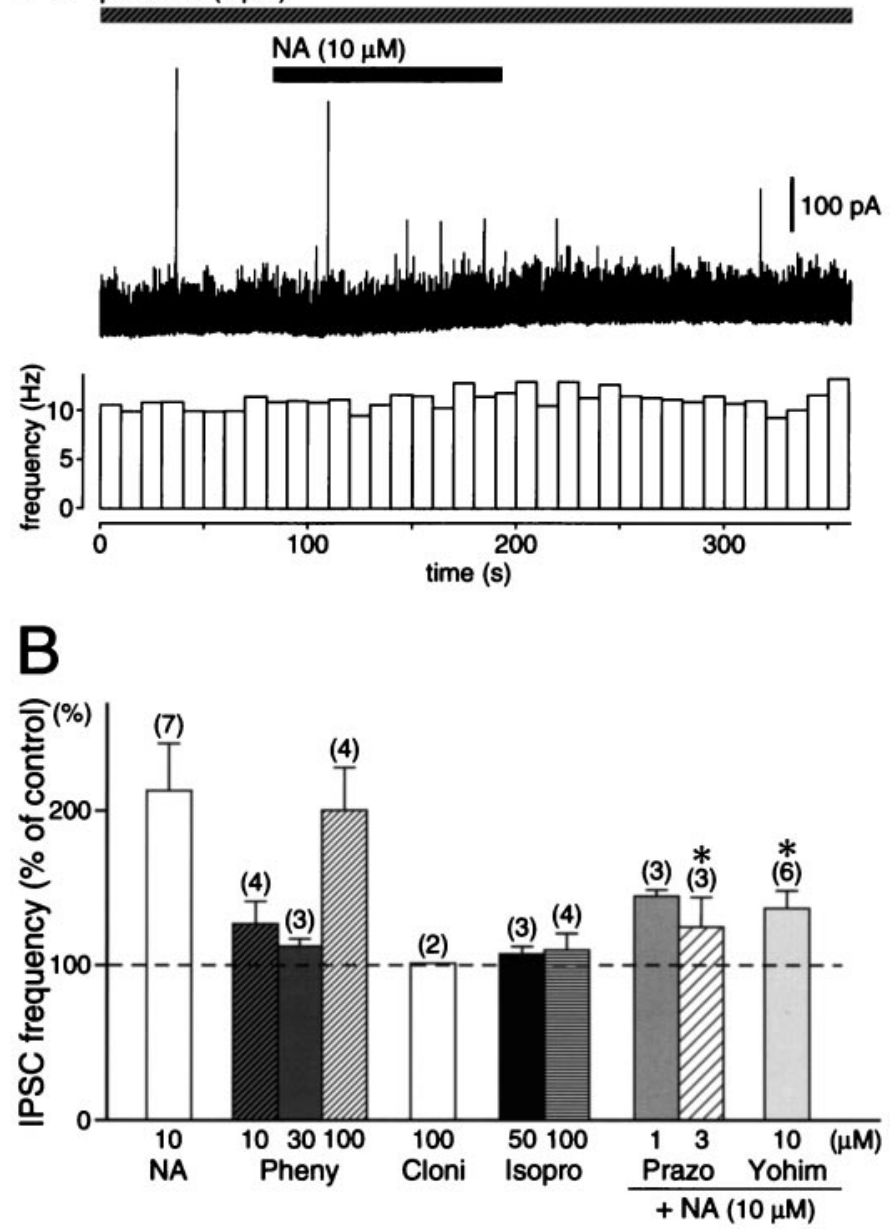

Figure 6. Pharmacological characterization of NA-induced GABAergic currents. $A$, An $\alpha 1$ antagonist prazosin $(3 \mu \mathrm{M})$ reduced the NA (10 $\mu \mathrm{M}$ )-induced increase of amplitude and frequency of GABAergic currents in a layer $\mathrm{V}$ pyramidal cell. $B$, Summary of the effects of adrenergic agonists on spontaneous IPSC frequency and of adrenergic antagonist on the NA-induced increase of IPSC frequency in a CNQX/APV-containing solution. Pheny, Phenylephrine ( $\alpha_{1}$-adrenergic agonist); Cloni, clonidine ( $\alpha_{2}$-adrenergic agonist); Isopro, isoproterenol ( $\beta$-adrenergic agonist). The data for agonists (NA, Pheny, Cloni, and Isopro) are normalized as a percentage of control values. The error bars represent SEM. The numbers of cells examined are given in parentheses. The effects of NA $(10 \mu \mathrm{M})$ in the presence or absence of prazosin (Prazo, $\alpha_{1}$-adrenergic antagonist) and yohimbine (Yohim, $\alpha_{2}$-adrenergic antagonist) were compared using MannWhitney $U$ test. $* p<0.01$.

the biocytin-labeled neurons were drawn using a camera lucida with a $60 \times$ or $100 \times$ oil-immersion lens. Terminal boutons were observed with differential interference contrast. The cross-sectional area and the longest extent of somata were measured in the $200 \mu \mathrm{m}$ sections containing whole stained cells using a computer-based image analysis system (National Institutes of Health Image).

Statistics. Paired $t$ tests were performed to compare the raw values of the control with the responses in the presence of adrenergic agonists applied to the same cells. Responses to agonists were also expressed as a percentage of the control obtained before the addition of the agonists. The effects of agonists, expressed as percentages, in the presence or absence of antagonists (two different groups of cells) were compared using Mann-Whitney $U$ tests. The effects of agonists in the presence or absence of TTX (two different groups of cells) were also compared using Mann-Whitney $U$ tests. The tests determined whether the decrease in the effect of the agonist was significant. 

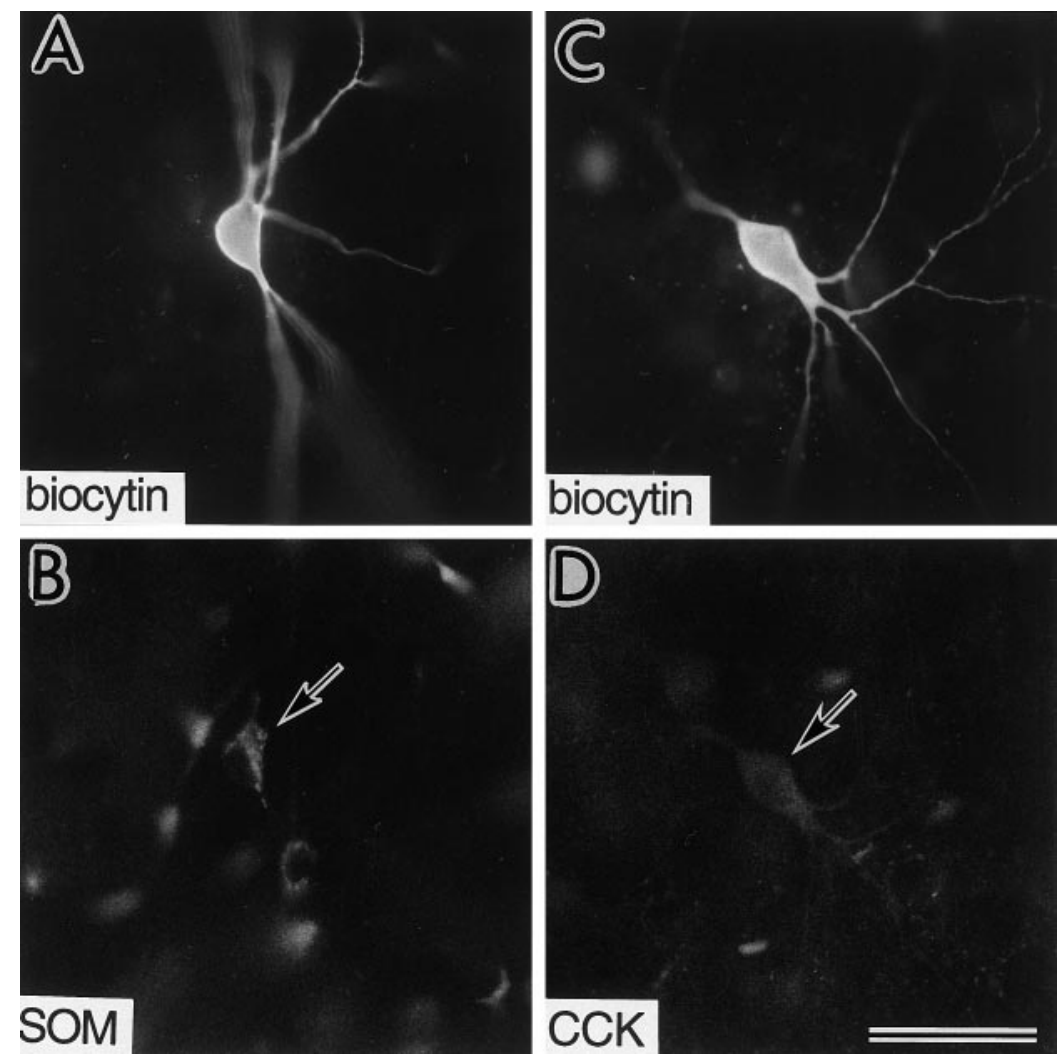

Figure 7. Immunohistochemical identification of regular/ burst-spiking nonpyramidal cells, in which the effects of NA or FNE were investigated. $A, B$, A biocytin-injected cell $(A)$ immunoreactive for somatostatin $(S O M)$ (arrow in $B)$. C, D, A biocytin-injected cell $(C)$ immunoreactive for cholecystokinin $(C C K)$ (arrow in $D)$. Scale bar, $50 \mu \mathrm{m}$.

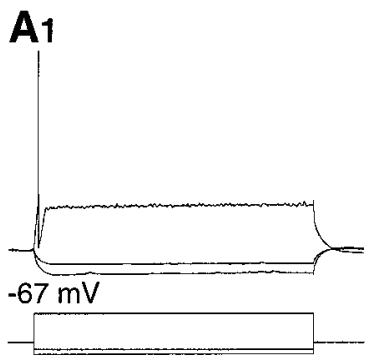

A2

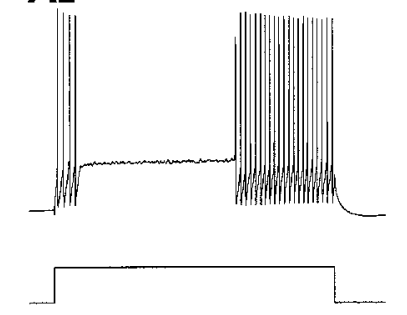

A3

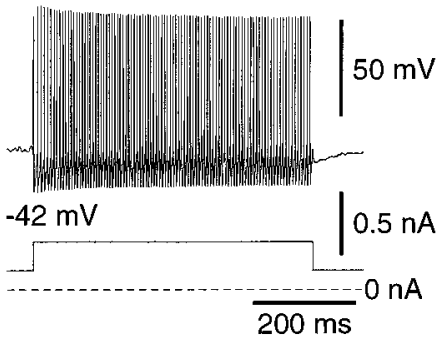

B

$\mathrm{NA}(10 \mu \mathrm{M})$

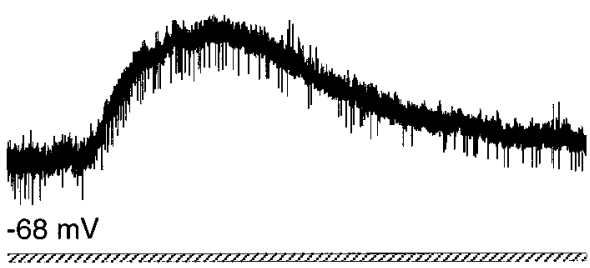

CNQX/APV

FS cells
C

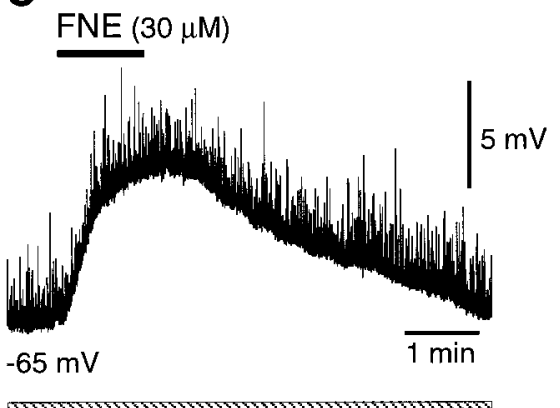

TTX
Figure 8. Depolarization of fast-spiking (FS) cells by application of NA or FNE. $A$, Spike discharges of an FS cell induced by current pulses. Resting potentials, -67 $\mathrm{mV}$. Note the abrupt start of nonadaptive firing $\left(A_{2}\right)$. Repetitive discharges were also fired at constant intervals with depolarizing pulses when combined with constant depolarization caused by the bias current $\left(A_{3}\right) . B$, The FS cell was depolarized by application of NA $(10 \mu \mathrm{M})$ in a solution containing $20 \mu \mathrm{M}$ CNQX and $50 \mu \mathrm{M}$ APV. FS cells did not fire with NA application alone. $C$, An FS cell was also depolarized by application of FNE $(30 \mu \mathrm{M})$ in a solution containing $0.5 \mu \mathrm{M}$ TTX.

\section{RESULTS}

\section{NA-induced increase of IPSC frequency in pyramidal cells}

To monitor the activity of GABAergic cells in the frontal cortex, spontaneous outward-going currents were recorded at holding potentials of $\sim 0 \mathrm{mV}$ in pyramidal cells in a solution containing blockers of excitatory transmission (10-20 $\mu \mathrm{M}$ CNQX and $50 \mu \mathrm{M}$
APV) (Fig. 1). Because these outward currents were reversibly suppressed by the $\mathrm{GABA}_{\mathrm{A}}$-receptor antagonist bicuculline (10 $\mu \mathrm{M}$ ), they were considered to be GABAergic IPSCs (Salin and Prince, 1996).

NA (3-50 $\mu \mathrm{M} ; n=25)$ induced a reversible increase in the frequency and amplitude of GABAergic currents in a solution containing CNQX and APV (CNQX/APV) (Fig. 2). The NA- 


\begin{tabular}{|c|c|c|c|c|c|c|c|c|c|c|c|}
\hline \multirow[b]{3}{*}{ GABA cell type } & \multirow[b]{3}{*}{$n$} & \multicolumn{4}{|c|}{ Cell characteristics } & \multicolumn{6}{|c|}{ Adrenergic responses } \\
\hline & & \multirow[b]{2}{*}{$\begin{array}{l}\text { Resting } \\
\text { potential } \\
(\mathrm{mV})\end{array}$} & \multirow[b]{2}{*}{$\begin{array}{l}\text { Input } \\
\text { resistance } \\
(\mathrm{M} \Omega)\end{array}$} & \multicolumn{2}{|c|}{ Cross-sectional somatic } & \multicolumn{2}{|c|}{$\begin{array}{l}\text { NA }(10-50 \mu \mathrm{M}) \\
\text { (number of cells) }\end{array}$} & \multicolumn{3}{|c|}{$\begin{array}{l}\text { FNE }(10-50 \mu \mathrm{M}) \\
\text { (number of cells) }\end{array}$} & \multirow{2}{*}{$\begin{array}{l}\text { Spike firing } \\
\text { (firing cells/ } \\
\text { total in } \\
\text { CNQX/APV) }\end{array}$} \\
\hline & & & & $\begin{array}{l}\text { Area } \\
\left(\mu \mathrm{m}^{2}\right)\end{array}$ & $\begin{array}{l}\text { Longest } \\
\text { extent } \\
(\mu \mathrm{m})\end{array}$ & Depo & $\begin{array}{l}\text { Hyper/ } \\
\text { Depo }\end{array}$ & Depo & $\begin{array}{l}\text { Hyper/ } \\
\text { Depo }\end{array}$ & Hyper & \\
\hline FS cells & 36 & $-70.1 \pm 4.9$ & $144 \pm 38$ & $151 \pm 37$ & $17.1 \pm 2.8$ & 9 & & 27 & & & $0 / 28(0 \%)$ \\
\hline LS cells & 7 & $-62.3 \pm 4.7$ & $184 \pm 51$ & $144 \pm 60$ & $16.2 \pm 3.6$ & 6 & & 1 & & & $0 / 6(0 \%)$ \\
\hline SOM RSNP cells & 21 & $-53.4 \pm 3.2$ & $332 \pm 100$ & $202 \pm 60$ & $19.7 \pm 3.3$ & 4 & 1 & 15 & 1 & & $12 / 13(92 \%)$ \\
\hline SOM BSNP cells & 3 & $-50.7 \pm 4.9$ & $400 \pm 39$ & $176 \pm 96$ & $18.3 \pm 3.1$ & & & 2 & 1 & & \\
\hline CCK RSNP cells & 22 & $-52.6 \pm 27.0$ & $360 \pm 102$ & $250 \pm 59$ & $22.8 \pm 4.2$ & 7 & 1 & 6 & 6 & 2 & $6 / 15(40 \%)$ \\
\hline CCK BSNP cells & 4 & $-58.0 \pm 2.7$ & $697 \pm 284$ & $225 \pm 43$ & $22.4 \pm 4.2$ & 4 & & & & & $2 / 4(50 \%)$ \\
\hline
\end{tabular}

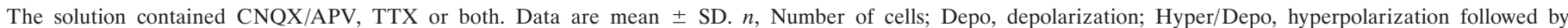

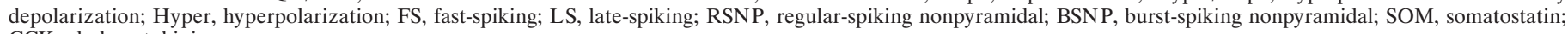
CCK, cholecystokinin.

${ }^{a}$ Proportion of cells that fired spikes in response to NA or FNE application in a solution containing CNQX/APV but not TTX.

\begin{tabular}{|c|c|c|c|c|c|}
\hline \multirow[b]{3}{*}{ GABA cell type } & \multirow[b]{3}{*}{ FNE concentration $(\mu \mathrm{M})$} & \multicolumn{4}{|c|}{$\underline{\text { FNE response patterns }}$} \\
\hline & & \multirow[b]{2}{*}{ Depo $(\mathrm{mV})$} & \multicolumn{2}{|l|}{ Hyper/Depo } & \multirow[b]{2}{*}{ Hyper $(\mathrm{mV}$} \\
\hline & & & Early hyper (mV) & Late depo $(\mathrm{mV})$ & \\
\hline \multirow[t]{3}{*}{ FS cells $(8)$} & $10(3)$ & $4.6 \pm 1.3(3)$ & & & \\
\hline & $30(2)$ & $6.3 \pm 1.3(2)$ & & & \\
\hline & $50(3)$ & $3.8 \pm 0.6(3)$ & & & \\
\hline LS cell $(1)$ & $50(1)$ & $5.3(1)$ & & & \\
\hline \multirow[t]{2}{*}{ SOM cells (11) } & $10(7)$ & $9.3 \pm 3.3(6)$ & -2 & $8.9(1)$ & \\
\hline & $30(4)$ & $7.3 \pm 0.8(3)$ & -1.8 & $7.6(1)$ & \\
\hline \multirow[t]{3}{*}{ CCK cells (7) } & $10(5)$ & $9.0 \pm 1.4(2)$ & $-2.0 \pm 2.0$ & $10.2 \pm 2.3(2)$ & $-20.8(1)$ \\
\hline & $30(1)$ & $16.4(1)$ & & & \\
\hline & $50(1)$ & & & & $-6.8(1)$ \\
\hline
\end{tabular}

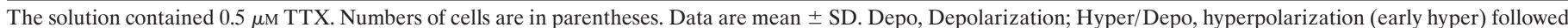

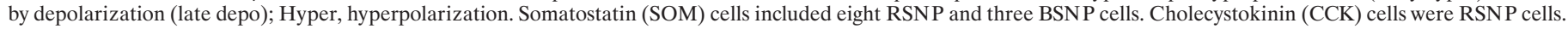

induced currents in a solution containing CNQX/APV were suppressed by TTX (Fig. 3A). GABAergic IPSCs larger than 30 $\mathrm{pA}$ were counted for measurement of the frequency over a period of 30-120 sec. The frequency of spontaneous IPSCs in layer V pyramidal cells $(n=7)$ was $2.89 \pm 1.26 / \mathrm{sec}($ mean $\pm \mathrm{SD})$ before the application, and $5.73 \pm 2.06 / \mathrm{sec}$ after the application of $10 \mu \mathrm{M}$ NA $[p<0.01$, paired $t$ test; $212 \pm 82 \%$ (SD) after application]. The frequency increase of IPSCs was also significant after application of 30 and $50 \mu \mathrm{M}$ NA $(p<0.05)$ (Fig. $3 B)$. Prior application of TTX $(0.5 \mu \mathrm{M} ; n=4)$ reduced the NA $(10 \mu \mathrm{M})$-induced increase of IPSC frequency to $126 \pm 12 \%(p<0.05$, MannWhitney $U$ test) (Fig. 3B).

\section{Involvement of $\alpha$-adrenoceptors in the tetrodotoxin- dependent increase of IPSC frequency}

The above results suggest that NA-induced IPSCs are caused by firing of GABAergic cells to a certain extent. Adrenoceptors are pharmacologically divided into $\alpha$ - and $\beta$-receptors, which are then further subclassified. Therefore, we determined which adrenoceptor types were involved in the excitation of GABAergic cells.

The IPSC frequency of pyramidal cells in a solution containing $\mathrm{CNQX} / \mathrm{APV}$ increased after application of a selective $\alpha$-adrenoceptor agonist, FNE (30-50 $\mu \mathrm{M})$ (Fig. 4). The FNEinduced currents were also suppressed immediately by TTX (1 $\mu \mathrm{M} ; n=4$ ) in a solution containing CNQX/APV (Fig. $5 A$ ).

The FNE-induced IPSCs were also blocked immediately by bicuculline (Fig. $5 B$ ). In addition, bicuculline abolished discrete GABAergic outward currents and induced inward currents (Fig. 1) (Salin and Prince, 1996), implying a sizeable background GABAergic current attributable to ambient GABA. Because this kind of phenomenon was not observed after application of TTX (Figs. $3 A, 5 A$ ), high levels of GABA may be released without firing of GABAergic cells in the cortex.

The frequency of spontaneous IPSCs in layer V pyramidal cells $(n=11)$ was increased from $4.82 \pm 2.57 / \mathrm{sec}$ (SD) before the application to $8.8 \pm 5.12 / \mathrm{sec}$ after the application of $50 \mu \mathrm{M} \mathrm{FNE}$ [ $p<0.01$, paired $t$ test; $188 \pm 51 \%$ (SD) after application]. A significant frequency increase was also observed with application of $30 \mu \mathrm{M}$ FNE $(p<0.01)$ (Fig. $5 C)$. Prior application of TTX $(0.3$ $\mu \mathrm{M} ; n=5)$ reduced the FNE $(50 \mu \mathrm{M})$-induced increase to $115 \pm$ 26\% ( $p<0.01$, Mann-Whitney $U$ test) (Fig. $5 C$ ).

$\alpha$-Adrenoceptors are pharmacologically divided into $\alpha_{1}$ - and $\alpha_{2}$-types. The effects of specific antagonists and agonists on IPSC frequency were investigated in a solution containing CNQX/ 
APV. An $\alpha_{1}$-adrenoceptor antagonist, prazosin $(1 \mu \mathrm{M}, n=3 ; 3$ $\mu \mathrm{M}, n=3)$, caused reduction of the NA $(10 \mu \mathrm{M})$-induced increase of IPSCs from $212 \pm 82 \%(n=7)$ to $126 \pm 31 \%(n=3)(p<$ 0.05, Mann-Whitney $U$ test) (Fig. 6A,B). An $\alpha_{2}$-adrenoceptor antagonist, yohimbine (10 $\mu \mathrm{M}, n=6)$, also reduced the NA (10 $\mu \mathrm{M})$-induced increase of IPSCs to $136 \pm 29 \%(p<0.05)$ (Fig. $6 B)$. A $\beta$-adrenoceptor antagonist, propranolol $(30 \mu \mathrm{M}, n=2)$, was without affect.

An $\alpha_{1}$-adrenoceptor agonist, phenylephrine, was applied at 10 , 30 , and $100 \mu \mathrm{M}$, the greatest dose increasing the IPSC frequency of layer V pyramidal cells $(2.75 \pm 1.09 / \mathrm{sec}$, control; $5.58 \pm 3.32$ / sec; $n=4$ ) (Fig. $6 B$ ). An $\alpha_{2}$-adrenoceptor agonist, clonidine $(100 \mu \mathrm{M})$, did not increase IPSC frequency (Fig. 6B). A $\beta$-adrenoceptor agonist, isoproterenol $(50 \mu \mathrm{M}, n=3$; $100 \mu \mathrm{M}, n=$ 4), did not increase IPSC frequency (Fig. $6 B$ ). These observations indicated the involvement of $\alpha$-adrenoceptors in the NA-induced excitation of GABAergic cells, although the subtype that was responsible could not be determined.

\section{Effects of NA and an $\alpha$-adrenergic agonist on GABAergic cell types}

The above results indicated that some GABAergic cells were excited by NA via $\alpha$-adrenoceptors, fired action potentials, and produced IPSCs in pyramidal cells. Because cortical GABAergic cells have been found to be physiologically and neurochemically heterogeneous, the effects of NA and the $\alpha$-adrenergic agonist FNE were investigated with respect to each type of GABAergic cell.

GABAergic nonpyramidal cells in the rat frontal cortex can be divided into three main physiological classes with regard to their firing patterns in response to depolarizing current pulses (Kawaguchi and Kubota, 1996, 1998). (1) Fast-spiking (FS) cells have lower input resistances than the other types of cells and show abrupt episodes of nonadapting repetitive discharges of short-duration spikes. (2) Late-spiking (LS) cells exhibit the ramp-like depolarizing response before spike firing during a square-wave current injection of threshold intensity. (3) The remaining cells include burst-spiking nonpyramidal (BSNP) and regular-spiking nonpyramidal (RSNP) cells. BSNP cells fire two or more spikes on slow depolarizing humps from hyperpolarized potentials. RS/BSNP cells are further classified on the basis of neuropeptide content, especially in layers II/III: (1) somatostatinimmunoreactive cells, (2) large CCK-immunoreactive cells, and (3) small VIP-immunoreactive cells. Somatostatin cells are negative for CCK and VIP. Small CCK cells demonstrate VIP immunoreactivity, whereas large CCK cells lack expression of VIP (Kawaguchi and Kubota, 1997, 1998; Kubota and Kawaguchi, 1997).

In the following experiments, each cell was physiologically identified as one of the above physiological classes before application of NA or FNE. NA or FNE was applied in solutions containing 10-20 $\mu \mathrm{M}$ CNQX and $50 \mu \mathrm{M}$ APV (CNQX/APV), 0.5 $\mu \mathrm{M}$ TTX, or both. Furthermore, RS/BSNP cells were neurochemically identified as positive for somatostatin or CCK by double-fluorescence immunohistochemistry after fixation (Fig. 7). We also investigated morphological characteristics of the FS, LS, somatostatin RS/BSNP, and CCK RS/BSNP cells, whose responses to NA or FNE had been determined. Three types of membrane potential change were observed in GABAergic cells by NA or FNE application: (1) depolarization, (2) hyperpolarization followed by depolarization, and (3) hyperpolarization.

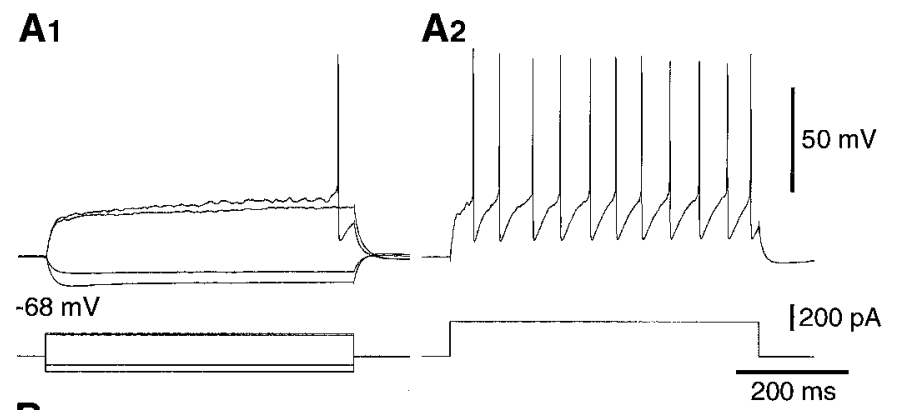

B

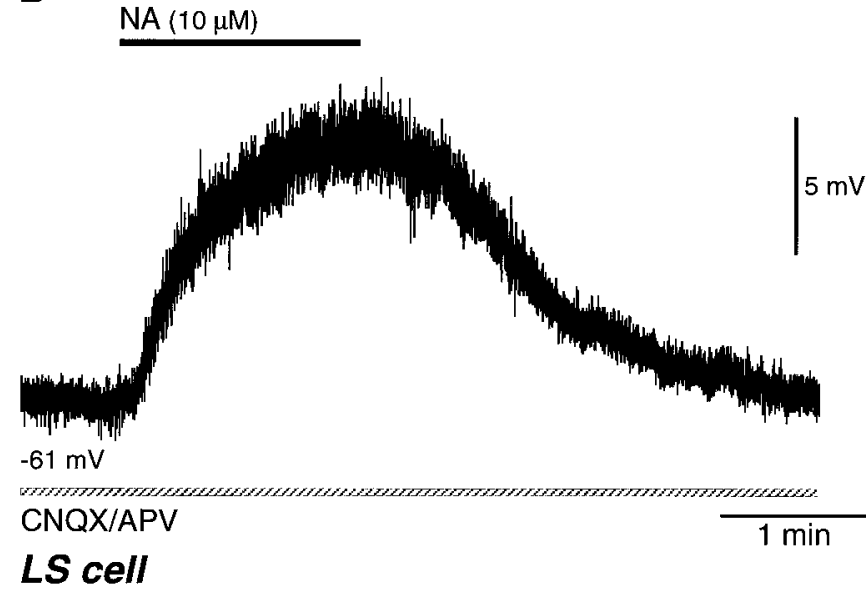

Figure 9. Noradrenergic depolarization of a late-spiking (LS) neurogliaform cell. $A_{1,2}$, Voltage responses of an LS cell induced by current pulses. Note the ramp-like depolarizing response to a square-wave current injection $\left(A_{1}\right)$. Resting potential, $-68 \mathrm{mV}$. $B$, The LS cell was depolarized during NA $(10 \mu \mathrm{M})$ application in a CNQX/APV-containing solution. LS cells did not fire with NA application.

\section{FS cells}

In response to depolarizing current pulses, FS cells started nonadapting repetitive discharges abruptly above some current intensity, and continuous repetitive firing was easily achieved when combined with constant depolarizations (Fig. 8A).

FS cells $(n=25$ in layers II/III, $n=11$ in layer V) were all depolarized by NA or FNE application (Fig. $8 B, C$, Table 1). In a CNQX/APV-containing solution, 28 FS cells were depolarized by $10 \mu \mathrm{M}$ NA $[5.8 \pm 2.5 \mathrm{mV}(\mathrm{SD}) ; n=4], 50 \mu \mathrm{M}$ NA $(6.0 \pm 1.8$ $\mathrm{mV} ; n=5)$, or $50 \mu \mathrm{M} \mathrm{FNE}(5.5 \pm 1.5 \mathrm{mV} ; n=19)$, but no spike firing was noted (Table 1). In a TTX-containing solution, FNE $(10-50 \mu \mathrm{M})$ also depolarized FS cells $(n=8)$ by $3-7 \mathrm{mV}$ (Table 2). The FS cells depolarized by NA or FNE were morphologically common multipolar cells with extended axonal arborizations (see Fig. $10 A-C$ ) and chandelier cells with vertical rows of axonal boutons (see Fig. 10D). Some terminals of common multipolar FS cells were apposed to other somata by multiple boutons. Axonal arborizations of the common FS cells were dense just above or around their somata (see Fig. 10A,C). The axon collaterals of some FS cells did not branch so frequently close to the somata as the above FS cells and ran more widely (see Fig. 10B).

\section{LS cells}

LS cells were identified by their ramp-like depolarizing response to a square-wave current injection of $0.5-1.0 \mathrm{sec}$ duration, which induced a spike at the end of a pulse (Fig. 9A).

Like FS cells, LS cells ( $n=7$ in layers II/III) were all depolarized by NA or FNE application (Fig. 9B, Table 1). In a 

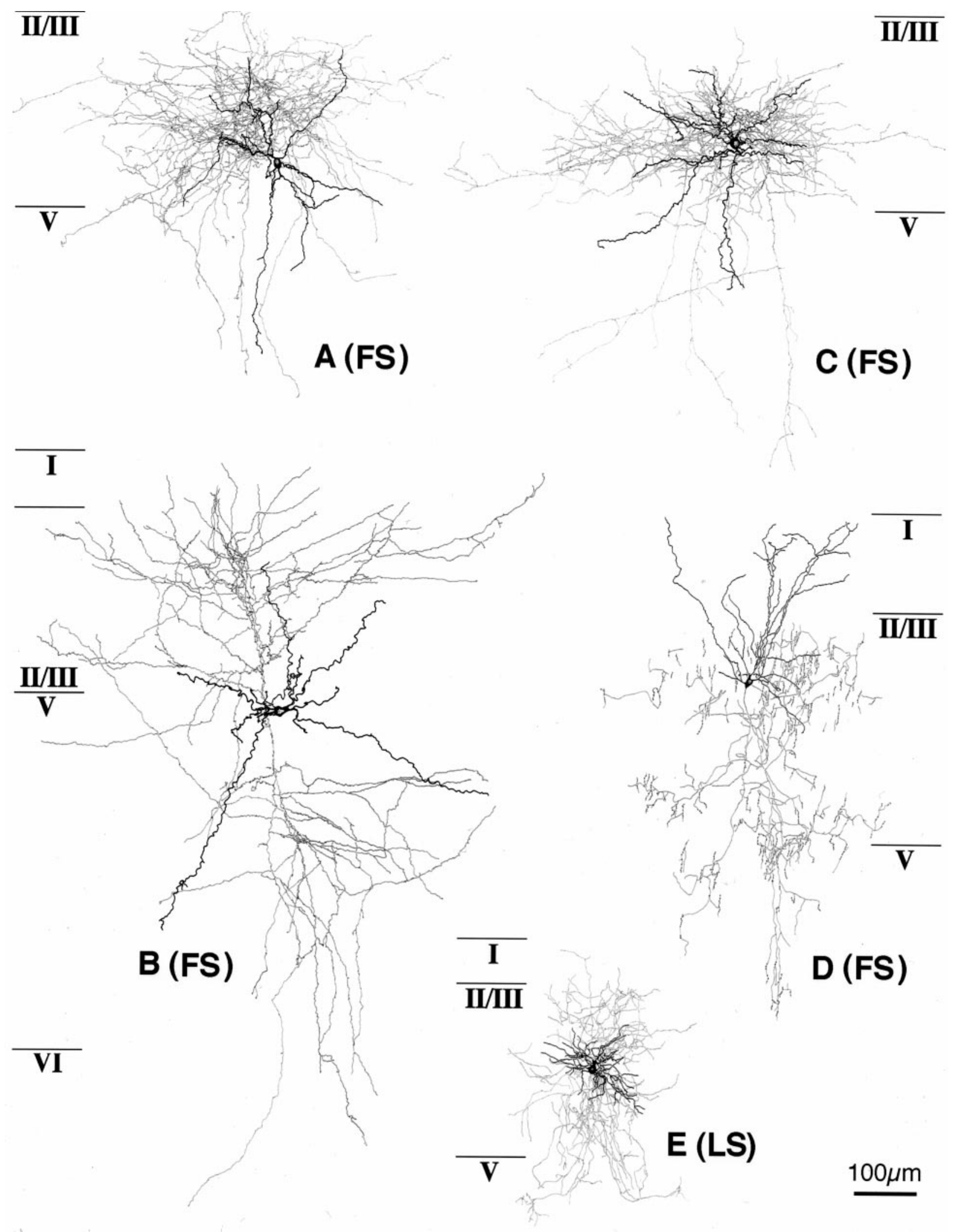

Figure 10. Four FS cells and an LS cell that were all depolarized by NA or FNE application in a solution containing CNQX/APV, TTX, or both. The somata and dendrites are shown in black and the axons in gray. Roman numerals correspond to the cortical layers. $A$, FS cell with dense innervation mainly above the cell body. $B$, FS cell with wide innervation. $C$, FS cell with dense innervation mainly at the level of the cell body. $D$, FS chandelier cell. $E$, LS neurogliaform cell. 


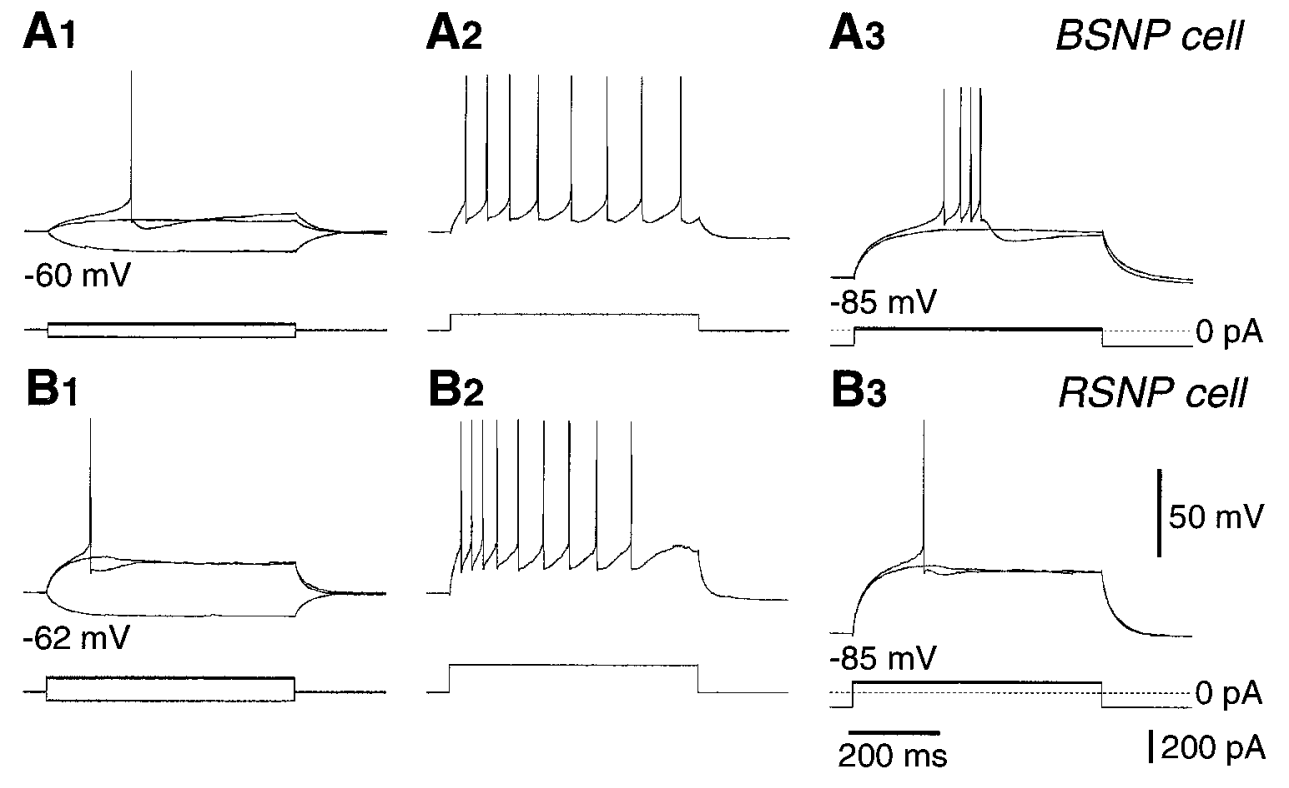

Figure 11. Burst-spiking nonpyramidal (BSNP) cells and regular-spiking nonpyramidal (RSNP) cells affected by application of NA or FNE. $A$, Voltage responses of a BSNP cell immunoreactive for CCK. Four action potentials on an all-or-none slow depolarizing potential were induced by a depolarizing current pulse from a hyperpolarized potential $(-85 \mathrm{mV})$ caused by the bias current $\left(A_{3}\right)$. Resting potential, $-60 \mathrm{mV}$. This neuron was depolarized by NA $(10 \mu \mathrm{M})$ application in a solution containing CNQX/APV. B, Voltage responses of an RSNP cell immunoreactive for CCK. Resting potential, $-62 \mathrm{mV}$. This neuron was hyperpolarized followed by depolarization by FNE $(30 \mu \mathrm{M})$ application in a solution containing CNQX/APV.
CNQX/APV-containing solution, six LS cells were depolarized by $10 \mu \mathrm{M}$ NA [ $6.2 \pm 2.9 \mathrm{mV}(\mathrm{SD}) ; n=3]$ or $50 \mu \mathrm{M}$ NA $(6.0 \pm 1.0$ $\mathrm{mV} ; n=3)$, but none fired spikes on the induced depolarizations (Table 1). An LS cell was depolarized by $50 \mu \mathrm{M}$ FNE in a TTX-containing solution (Table 2). The LS cells depolarized by NA or FNE included morphologically neurogliaform cells (Fig. 10E).

\section{Somatostatin RS/BSNP cells}

Somatostatin or CCK cells were of BSNP or RSNP type. BSNP cells fired two or more spikes on slow depolarizing humps from hyperpolarized potentials (Fig. 11A). RSNP cells did not show fast-spiking characteristics, spike bursts on depolarization from negative membrane potentials, or ramp-like depolarizing responses before spike generation (Fig. 11B). Nonpyramidal cells not categorized into one of the FS, LS, and BSNP groups were categorized as RSNP cells.

NA or FNE was applied to 21 somatostatin RSNP cells $(n=20$ in layers II/III, $n=1$ in layer V) and 3 somatostatin BSNP cells ( $n=1$ in layers II/III, $n=2$ in layer V) (Table 1$)$.

Most somatostatin cells (19 RSNP and 2 BSNP cells) were depolarized by NA or FNE application (Fig. 12A,B, Table 1). In a CNQX/APV-containing solution, 12 somatostatin cells were depolarized by $10 \mu \mathrm{M}$ NA $(n=3), 50 \mu \mathrm{M}$ NA $(n=1), 10 \mu \mathrm{M} \mathrm{FNE}$ $(n=4)$, or $30 \mu \mathrm{M} \mathrm{FNE}(n=4)$, and 11 cells fired spikes on the induced depolarization (Fig. 12A). In a TTX-containing solution, nine somatostatin cells were also depolarized by 10-30 $\mu \mathrm{M} \mathrm{FNE}$ (Fig. 12B, Table 2).

A few somatostatin cells (two RSNP and one BSNP) exhibited NA- or FNE-induced hyperpolarization followed by depolarization (Table 1). By application of $10 \mu \mathrm{M}$ NA in a CNQX/APVcontaining solution, a somatostatin cell elicited spikes on the depolarization after weak hyperpolarization $(-0.7 \mathrm{mV})$ (Fig. $12 C$ ). In a TTX-containing solution, two somatostatin cells were also hyperpolarized and later depolarized by 10-30 $\mu \mathrm{M}$ FNE (Table 2).

By application of NA or FNE in a solution containing CNQX/ APV, but not TTX, 92\% of somatostatin RSNP cells elicited spikes (Table 1).

These somatostatin cells morphologically included multipolar or bitufted cells with mainly ascending axonal arbors (Martinotti cells; see Fig. 14A) or with axonal arbors extending in all orientations (wide arbor cells; see Fig. 14B).

\section{CCK RS/BSNP cells}

NA or FNE was applied to 22 CCK RSNP cells ( $n=21$ in layers II/III, $n=1$ in layer V) and 4 CCK BSNP cells $(n=4$ in layers II/III) (Table 1). From the somatic size, these cells appeared to belong to the large CCK cell category (Kubota and Kawaguchi, 1997; Kawaguchi and Kubota, 1998). Their responses to NA or FNE application were depolarization, hyperpolarization followed by depolarization, or hyperpolarization.

Seventeen CCK cells (13 RSNP and 4 BSNP cells) were depolarized by NA or FNE application (Fig. 13A, Table 1). In a CNQX/APV-containing solution, $14 \mathrm{CCK}$ cells were depolarized by $10 \mu \mathrm{M}$ NA $(n=9), 50 \mu \mathrm{M}$ NA $(n=2), 10 \mu \mathrm{M} \operatorname{FNE}(n=1)$, or $30 \mu \mathrm{M} \mathrm{FNE}(n=2)$, accompanied by spike firing in six cases (Fig. 13A). In a TTX-containing solution, three CCK cells were also depolarized by $10 \mu \mathrm{M} \mathrm{FNE}(n=2)$ or $30 \mu \mathrm{M} \operatorname{FNE}(n=1)$ (Table 2).

Seven CCK RSNP cells exhibited hyperpolarization followed by depolarization by application of NA or FNE (Fig. 13B,C, Table 1). In a CNQX/APV-containing solution, five CCK cells were hyperpolarized and later depolarized by NA or FNE. The early hyperpolarization was $-3.3 \mathrm{mV}$ in $10 \mu \mathrm{M} \mathrm{NA},-3.3$ and $-6.7 \mathrm{mV}$ in $10 \mu \mathrm{M} \mathrm{FNE}$, and -5.8 and $-6.2 \mathrm{mV}$ in $30 \mu \mathrm{M} \mathrm{FNE}$. In two cells, spikes occurred on the late depolarization (Fig. 13B). In a TTX-containing solution, two CCK cells were also hyperpolarized and later depolarized by $10 \mu \mathrm{M}$ FNE (Fig. 13C, Table 2).

Two CCK RSNP cells were only hyperpolarized by application of 10 or $50 \mu \mathrm{M} \mathrm{FNE}$ in a TTX-containing solution (Fig. 13D, Tables 1, 2).

By application of NA or FNE in a solution containing CNQX/ APV, but not TTX, $40 \%$ of CCK RSNP cells and $50 \%$ of CCK BSNP cells elicited spikes (Table 1).

These CCK cells morphologically included large multipolar or bitufted cells making boutons apposed to other cell bodies (large basket cells) (Fig. 14C). Morphological differences among the three types of CCK cells with different adrenergic responses could not be found. 

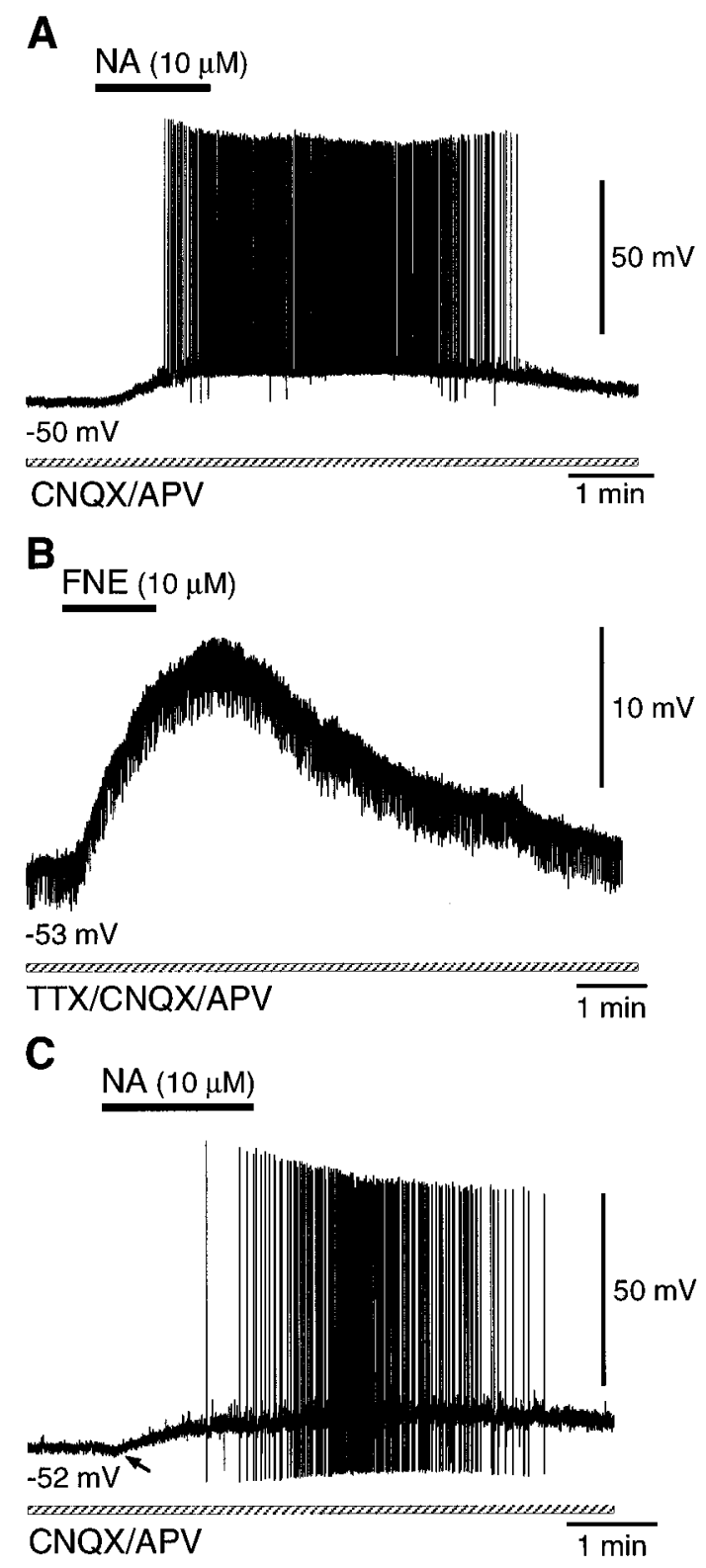

\section{Somatostatin cells}

Figure 12. Noradrenergic effects on somatostatin-immunoreactive cells. $A$, A somatostatin cell was depolarized with spike discharges by NA (10 $\mu \mathrm{M})$ application in a solution containing CNQX/APV. B, A somatostatin cell was depolarized by FNE $(10 \mu \mathrm{M})$ application in a solution containing TTX and CNQX/APV. $C$, A somatostatin cell was minimally hyperpolarized (arrow) followed by depolarization with spike discharges by NA $(10 \mu \mathrm{M})$ application in a solution containing CNQX/APV.

\section{DISCUSSION}

The major findings of the present study in the frontal cortex of young rats can be summarized as follows. (1) NA or a selective $\alpha$-adrenoceptor agonist, FNE, but not a selective $\beta$-adrenoceptor agonist, isoproterenol, induced an increase of GABAergic IPSC frequency in pyramidal cells in a solution containing antagonists for ionotropic glutamate receptors. (2) The NA-induced increase of IPSC frequency was reduced by TTX and $\alpha$-adrenergic antagonists. (3) NA or FNE directly affected the activities of most GABAergic cell types. (4) NA or FNE induced depolarization but not firing in FS cells, including common multipolar cells with extended axonal arborizations as well as chandelier cells, and in LS neurogliaform cells. (5) Most somatostatin RS/BSNP cells, including Martinotti cells and wide arbor cells, were depolarized, accompanied by spike firing, but a few somatostatin cells exhibited hyperpolarization followed by depolarization, accompanied by spike firing. (6) CCK RS/BSNP cells, including large basket cells, were affected heterogeneously: depolarization, hyperpolarization followed by depolarization, and hyperpolarization were all observed.

\section{Noradrenergic increase of GABAergic IPSCs}

Adrenergic induction of IPSCs has been observed in several regions. The frequency of spontaneous IPSCs is increased by adrenaline in the sensorimotor cortex (Bennett et al., 1998). In the pyriform cortex, NA increases GABAergic IPSP frequency in pyramidal cells and also increases the firing rate of many interneurons via $\alpha_{1}$-adrenoceptors (Gellman and Aghajanian, 1993; Marek and Aghajanian, 1996). In the hippocampus, the frequency of TTX-sensitive GABAergic spontaneous IPSPs is increased by NA, epinephrine, or FNE, suggesting an involvement of the $\alpha$-adrenoceptor (Doze et al., 1991). This increase is attributable to $\alpha_{1}$-adrenoceptor-mediated excitation of hippocampal interneurons (Bergles et al., 1996). In the medial septum and diagonal Band of Broca, NA causes TTX-sensitive GABAergic synaptic potentials in cholinergic and GABAergic neurons through $\alpha_{1}$ adrenergic excitation of a subpopulation of septohippocampal neurons (Alreja and Liu, 1996). These indicate that NA induces IPSPs by excitation of some GABAergic cells via an $\alpha$-adrenoceptor in the local circuits of the forebrain.

Iontophoretically applied NA in vivo decreases or enhances the spontaneous activity and the activity evoked by sensory stimuli of cortical cells (Bevan et al., 1977; Waterhouse and Woodward, 1980; Armstrong-James and Fox, 1983; Videen et al., 1984; Kolta et al., 1987; Bassant et al., 1990; Warren and Dykes, 1996), whereas its application in vitro usually increases the excitability of pyramidal cells. $\beta$-Receptor activation suppresses the afterhyperpolarization after spikes by the blockade of a slow $\mathrm{Ca}^{2+}$-activated $\mathrm{K}^{+}$conductance, resulting in enhancement of neuronal excitability on current injection (Haas and Konnerth, 1983; Madison and Nicoll, 1986; Foehring et al., 1989; Dodt et al., 1991). NA depolarizes layer $\mathrm{V}$ burst-generating pyramidal cells via $\alpha_{1}$-receptors, shifting firing patterns from spontaneously bursting to singlespike activity (Wang and McCormick, 1993). NA can also affect both excitatory and inhibitory synaptic transmission through activation of presynaptic adrenoceptors (Madison and Nicoll, 1988; Dodt et al., 1991; Doze et al., 1991; Scanziani et al., 1993; Gereau and Conn, 1994; Bennett et al., 1997, 1998). Complex actions of NA application on cortical cells in vivo may thus result from the interaction of direct excitatory postsynaptic effects and presynaptic regulation of excitatory and inhibitory inputs via adrenoceptor types.

\section{Excitation and inhibition of GABAergic cells via $\alpha$-adrenoceptors}

In the present study, most GABAergic cells were depolarized by NA or FNE application, but some CCK-containing cells and a few somatostatin-containing cells exhibited hyperpolarization preceding depolarization. A few CCK cells were only hyperpolarized. Responses of small VIP cells to NA application were not investigated. Because most somatostatin cells fired spikes on the NA-induced depolarization, these GABAergic cells are consid- 

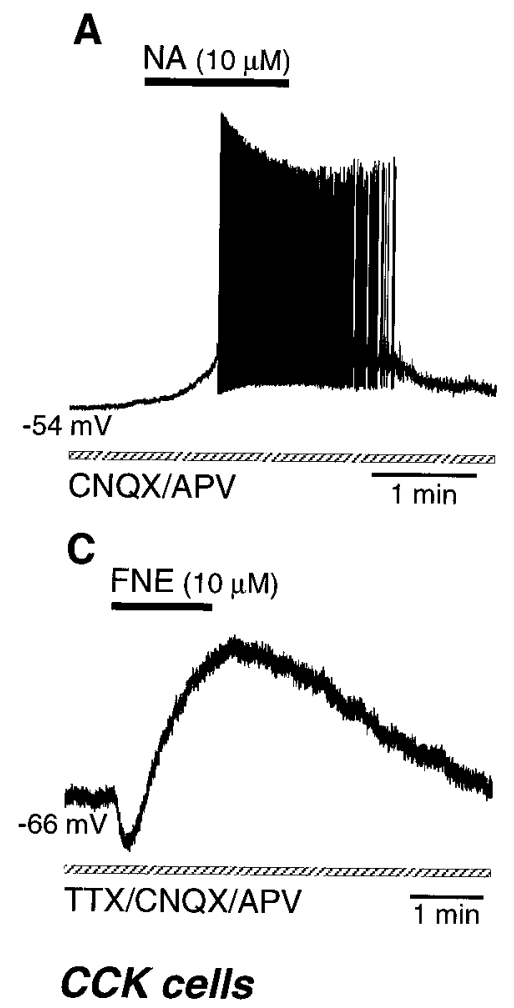
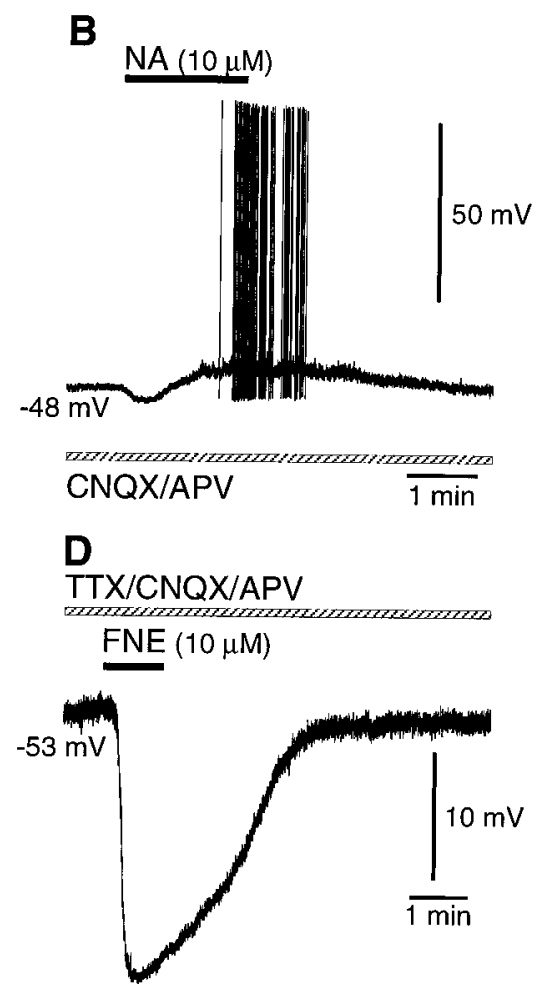

Figure 13. Noradrenergic effects on CCK-immunoreactive cells. $A$, A CCK cell was depolarized with spike discharges by NA $(10 \mu \mathrm{M})$ application in a solution containing CNQX/ APV. B, A CCK cell demonstrated hyperpolarization followed by depolarization with spike discharges after NA (10 $\mu \mathrm{M})$ application in a solution containing CNQX/APV. C, A CCK cell was hyperpolarized and then depolarized by FNE $(10 \mu \mathrm{M})$ application in a solution containing TTX and CNQX/APV. $D$, A CCK cell was hyperpolarized by FNE $(10 \mu \mathrm{M})$ application in a solution containing TTX and CNQX/APV. ered to contribute to NA-induced increase of spontaneous IPSC in vitro slice preparations. Some CCK cells may also contribute to NA-induced induction of IPSCs in pyramidal cells.

Because these induced depolarizations or hyperpolarizations were observed in both TTX- and CNQX/APV-containing solutions, the responses are most likely direct actions of NA or FNE on GABAergic cells. However, NA or FNE may affect the membrane potentials of GABAergic cells through the change of tonic inhibitions attributable to the action potential-independent release of GABA because bicuculline was not included in the solutions. The TTX-insensitive tonic GABAergic currents were observed in pyramidal cells (Figs. 1, 3A, 5A,B).

Activation of $\alpha$-adrenoceptors has been shown to induce depolarization in other forebrain areas. NA-induced depolarization is considered to be caused by modulation of $\mathrm{K}^{+}$currents (Nicoll et al., 1990). In the hypothalamus and thalamus, NA-evoked depolarizations are reduced by membrane hyperpolarization and by raising extracellular $\mathrm{K}^{+}$(Randle et al., 1986; McCormick and Prince, 1988). In hippocampal interneurons it is attributed primarily to the $\alpha_{1}$ adrenoceptor-mediated decrease in $\mathrm{K}^{+}$conductance (Bergles et al., 1996). NA-induced hyperpolarization through $\alpha_{2}$ adrenoceptors is observed mainly in the brain stem and spinal cord (Nicoll et al., 1990). Because some CCK cells and a few somatostatin cells exhibited NA-induced hyperpolarization in addition to depolarization, some peptide-containing cortical GABAergic cells may express adrenoceptor types mediating opposing effects, which may be distributed on different domains of the cell surface.

NA is considered to be released diffusely to the extracellular space from the noradrenergic axons (Séguéla et al., 1990). The selectivity and specificity of NA action may be caused by the distribution of adrenoceptors. It is known that several types of $\alpha$ and $\beta$-adrenoceptors are expressed in cortical cells (Nicholas et al., 1996). The expression of $\alpha$-adrenoceptors in cortical GABAergic cell types needs to be clarified.

\section{Adrenergic modulation of GABAergic inhibition on pyramidal cells}

In the present study, application of NA increased spontaneous $\mathrm{GABA}_{\mathrm{A}}$ receptor-mediated IPSCs through excitation of GABAergic cells, which may cause tonic shunting inhibition in pyramidal cells. Different from spontaneous IPSCs, evoked IPSCs in pyramidal cells by electrical stimulation of the sensorimotor cortex are depressed, enhanced, or not affected by adrenoceptor activation, although spontaneous IPSC frequency is increased in all cells (Bennett et al., 1997, 1998). These diverse adrenergic effects on spontaneous and evoked IPSCs suggest that noradrenergic inputs may differentially regulate tonic and phasic inhibition in cortical pyramidal cells. In hippocampus, cholinergic agonists excite some GABAergic interneurons but also suppress the synaptic release of some GABAergic terminals (Pitler and Alger, 1992; Behrends and ten Bruggencate, 1993). There is a differential distribution of a muscarinic acetylcholine receptor type $(\mathrm{m} 2)$ in the somadendritic versus axonal domains of different interneuron types in the hippocampal formation (Hájos et al., 1998). Cortical adrenoceptors may also be differentially distributed in the somata, dendrites, or axon terminals. Noradrenergic inputs could modify spatial and temporal patterns of intracortical GABAergic inhibition by affecting adrenoceptor types distributing on specific domains of the neuronal surface of different GABAergic cell types.

\section{Differential monoaminergic and cholinergic modulation among GABAergic cell types}

Like NA action through $\alpha$-adrenoceptors, the cholinergic agonist carbachol exerts differential effects on GABAergic cell types through muscarinic receptors at the concentrations inducing 


\section{A (SOM)}

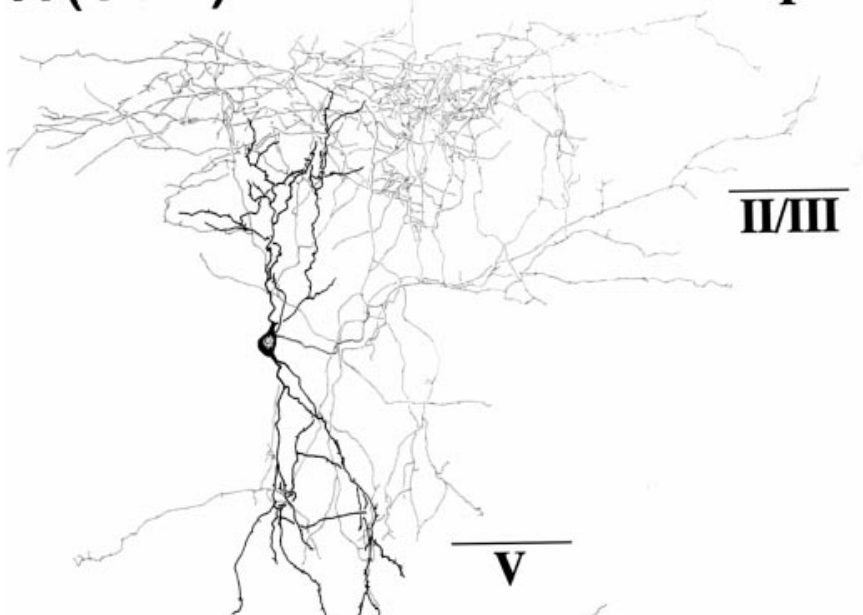

B (SOM)

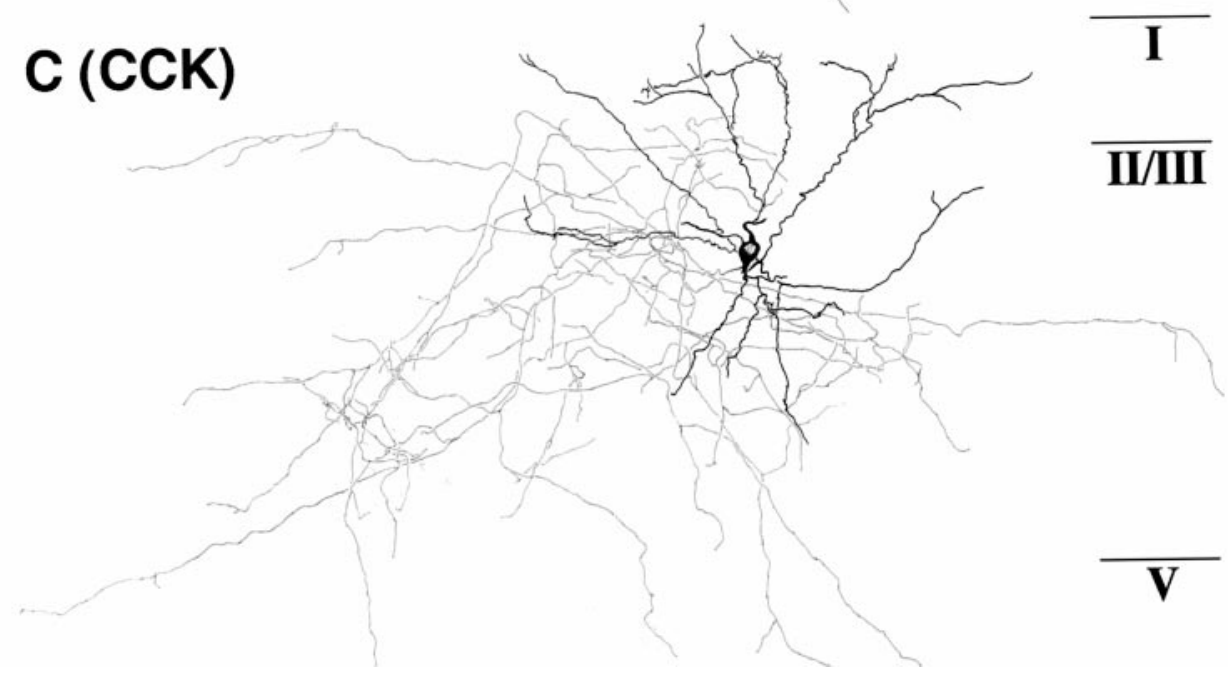

Figure 14. Two somatostatin cells and a CCK cell affected by NA or FNE application. The somata and dendrites are shown in black and the axons in gray. A, A somatostatin cell with ascending axonal arbors. This neuron was depolarized by FNE $(10 \mu \mathrm{M})$ application in a solution containing TTX. $B$, A somatostatin cell with wide axonal arbors. This neuron was depolarized with spike discharges by FNE $(30 \mu \mathrm{M})$ application in a solution containing CNQX/APV. $C$, A large CCK cell with axonal arbors making multiple boutons on other cell bodies. This neuron was hyperpolarized and then demonstrated depolarization with spike discharges on FNE $(10 \mu \mathrm{M})$ application in a solution containing CNQX/APV.

IPSCs in pyramidal cells (Kawaguchi, 1997). FS and LS cells are depolarized by NA but not by carbachol. NA-induced depolarization does not induce spike firing at the resting potentials in FS and LS cells. Somatostatin cells are mostly depolarized by both NA and carbachol, accompanied by spike firing. Large CCK cells are mostly hyperpolarized, followed by a slow depolarization by carbachol, but exhibit heterogeneous responses to NA: depolarization, hyperpolarization followed by depolarization, or hyperpolarization. Small VIP cells including some CCK cells are depolarized by carbachol, accompanied by spike firing. The GABAergic cell types are considered to regulate different domains of cortical cells (Kawaguchi and Kubota, 1997). The 
present results suggest that NA and acetylcholine may exert different influences on cortical activity through selective regulation of GABAergic cell types, although both transmitters are involved in cortical activation.

In addition to NA, there are other monoaminergic ascending systems such as serotonin (5-HT), histamine, and dopamine, which are also considered to control the pattern of activity and level of excitability in the cortex (Nicoll et al., 1990; McCormick, 1992). There is a strong interaction between 5-HT axon terminals and specific GABAergic neurons (DeFelipe et al., 1991; Hornung and Celio, 1992). The type 3 serotonin $\left(5-\mathrm{HT}_{3}\right)$ receptor is expressed in cortical GABAergic cells containing CCK but not somatostatin or parvalbumin (Morales and Bloom, 1997). 5- $\mathrm{HT}_{3}$ receptor agonists enhance the frequency of spontaneous GABAergic synaptic currents in developing ferret visual cortex (Roerig and Katz, 1997). Other monoaminergic inputs to the cortex may also regulate GABAergic cell types differentially.

\section{Conclusions}

GABAergic cell types have been identified in the rat frontal cortex on the basis of their firing responses to a depolarizing current, axon arborization patterns, synaptic connections, and coexpression of neuroactive substances (Kawaguchi and Kubota, 1997). The differences in noradrenergic responses among GABAergic cell types suggest a distinct functional role of each type. The different actions of NA and acetylcholine on the same GABAergic cell type implies that NA and acetylcholine may influence the activity of cortical circuitry differentially.

\section{REFERENCES}

Alreja M, Liu W (1996) Noradrenaline induces IPSCs in rat medial septal/diagonal band neurons: involvement of septohippocampal GABAergic neurons. J Physiol (Lond) 494:201-215.

Armstrong-James M, Fox K (1983) Effects of ionophoresed noradrenaline on the spontaneous activity of neurones in rat primary somatosensory cortex. J Physiol (Lond) 335:427-447.

Aston-Jones G, Chiang C, Alexinsky T (1991) Discharge of noradrenergic locus coeruleus neurons in behaving rats and monkeys suggests a role in vigilance. In: Progress in brain research, Vol 88, Neurobiology of the locus coeruleus (Barnes CD, Pompeiano O, eds), pp 501-520. Amsterdam: Elsevier.

Bassant MH, Ennouri K, Lamour Y (1990) Effects of iontophoretically applied monoamines on somatosensory cortical neurons of unanesthetized rats. Neuroscience 39:431-439.

Behrends JC, ten Bruggencate G (1993) Cholinergic modulation of synaptic inhibition in the guinea pig hippocampus in vitro: excitation of GABAergic interneurons and inhibition of GABA-release. J Neurophysiol 69:626-629.

Benardo LS (1993) Characterization of cholinergic and noradrenergic slow excitatory postsynaptic potentials from rat cerebral cortical neurons. Neuroscience 53:11-22.

Bennett BD, Huguenard JR, Prince DA (1997) Adrenoceptor-mediated elevation of ambient GABA levels activates presynaptic $\mathrm{GABA}_{\mathrm{B}}$ receptors in rat sensorimotor cortex. J Neurophysiol 78:561-566.

Bennett BD, Huguenard JR, Prince DA (1998) Adrenergic modulation of $\mathrm{GABA}_{\mathrm{A}}$ receptor-mediated inhibition in rat sensorimotor cortex. J Neurophysiol 79:937-946.

Bergles DE, Doze VA, Madison DV, Smith SJ (1996) Excitatory actions of norepinephrine on multiple classes of hippocampal CA1 interneurons. J Neurosci 16:572-585.

Berridge CW, Foote SL (1991) Effects of locus coeruleus activation on electroencephalographic activity in neocortex and hippocampus. J Neurosci 11:3135-3145.

Bevan P, Bradshaw CM, Szabadi E (1977) The pharmacology of adrenergic neuronal responses in the cerebral cortex: evidence for excitatory alpha- and inhibitory beta-receptors. Br J Pharmacol 59:635-641.

DeFelipe J, Hendry SHC, Hashikawa T, Jones EG (1991) Synaptic relationships of serotonin-immunoreactive terminal baskets on GABA neurons in the cat auditory cortex. Cereb Cortex 1:117-133.
Demeulemeester H, Vandesande F, Orban GA, Brandon C, Vanderhaeghen JJ (1988) Heterogeneity of GABAergic cells in cat visual cortex. J Neurosci 8:988-1000.

Dodt HU, Pawelzik H, Zieglansberger W (1991) Actions of noradrenaline on neocortical neurons in vitro. Brain Res 545:307-311.

Doze VA, Cohen GA, Madison DV (1991) Synaptic localization of adrenergic disinhibition in the rat hippocampus. Neuron 6:889-900.

Foehring RC, Schwindt PC, Crill WE (1989) Norepinephrine selectively reduces slow $\mathrm{Ca}^{2+}$ - and $\mathrm{Na}^{+}$-mediated $\mathrm{K}^{+}$currents in cat neocortical neurons. J Neurophysiol 61:245-256.

Foote SL, Berridge CW, Adams LM, Pineda JA (1991) Electrophysiological evidence for the involvement of the locus coeruleus in alerting, orienting, and attending. In: Progress in brain research, Vol 88, Neurobiology of the locus coeruleus (Barnes $\mathrm{CD}$, Pompeiano O, eds), pp 521-532. Amsterdam: Elsevier.

Gellman RL, Aghajanian GK (1993) Pyramidal cells in piriform cortex receive a convergence of inputs from monoamine activated GABAergic interneurons. Brain Res 600:63-73.

Gereau RW, Conn PJ (1994) Presynaptic enhancement of excitatory synaptic transmission by beta-adrenergic receptor activation. J Neurophysiol 72:1438-1442.

Haas HL, Konnerth A (1983) Histamine and noradrenaline decrease calcium-activated potassium conductance in hippocampal pyramidal cells. Nature 302:432-434.

Hájos N, Papp ECS, Acsády L, Levey AI, Freund TF (1998) Distinct interneuron types express $\mathrm{m} 2$ muscarinic receptor immunoreactivity on their dendrites or axon terminals in the hippocampus. Neuroscience 82:355-376.

Hornung JP, Celio MR (1992) The selective innervation by serotoninergic axons of calbindin-containing interneurons in the neocortex and hippocampus of the marmoset. J Comp Neurol 320:457-467.

Jones BE (1993) The organization of central cholinergic systems and their functional importance in sleep-waking states. In: Progress in brain research, Vol 98, Cholinergic function and dysfunction (Cuello AC, ed), pp 61-71. Amsterdam: Elsevier.

Kawaguchi Y (1997) Selective cholinergic modulation of cortical GABAergic cell subtypes. J Neurophysiol 78:1743-1747.

Kawaguchi Y, Kubota Y (1996) Physiological and morphological identification of somatostatin- or vasoactive intestinal polypeptide-containing cells among GABAergic cell subtypes in rat frontal cortex. J Neurosci 16:2701-2715.

Kawaguchi Y, Kubota Y (1997) GABAergic cell subtypes and their synaptic connections in rat frontal cortex. Cereb Cortex 7:476-486.

Kawaguchi Y, Kubota Y (1998) Neurochemical features and synaptic connections of large physiologically-identified GABAergic cells in the rat frontal cortex. Neuroscience 85:677-701.

Kolta A, Diop L, Reader TA (1987) Noradrenergic effects on rat visual cortex: single-cell microiontophoretic studies of alpha-2 adrenergic receptors. Life Sci 41:281-289.

Kubota Y, Kawaguchi Y (1997) Two distinct subgroups of cholecystokinin-immunoreactive cortical interneurons. Brain Res 752:175-183.

Kubota Y, Hattori R, Yui Y (1994) Three distinct subpopulations of GABAergic neurons in rat frontal agranular cortex. Brain Res 649:159-173.

Madison DV, Nicoll RA (1986) Actions of noradrenaline recorded intracellularly in rat hippocampal CA1 pyramidal neurones, in vitro. J Physiol (Lond) 372:221-244.

Madison DV, Nicoll RA (1988) Norepinephrine decreases synaptic inhibition in the rat hippocampus. Brain Res 442:131-138.

Marek GJ, Aghajanian GK (1996) $\alpha_{1 \mathrm{~B}}$-Adrenoceptor-mediated excitation of piriform cortical interneurons. Eur J Pharmacol 305:95-100.

McCormick DA (1992) Neurotransmitter actions in the thalamus and cerebral cortex and their role in neuromodulation of thalamocortical activity. Prog Neurobiol 39:337-388.

McCormick DA, Prince DA (1986) Mechanisms of action of acetylcholine in the guinea pig of cerebral cortex in vitro. J Physiol (Lond) 375:169-194.

McCormick DA, Prince DA (1988) Noradrenergic modulation of firing pattern in guinea pig and cat thalamic neurons in vitro. J Neurophysiol 59:978-996.

Metherate R, Cox CL, Ashe JH (1992) Cellular bases of neocortical activation: modulation of neural oscillations by the nucleus basalis and endogenous acetylcholine. J Neurosci 12:4701-4711.

Morales M, Bloom FE (1997) The 5-HT 3 receptor is present in different 
subpopulations of GABAergic neurons in the rat telencephalon. J Neurosci 17:3157-3167.

Morrison JH, Grzanna R, Molliver ME, Coyle JT (1978) The distribution and orientation of noradrenergic fibers in neocortex of the rat: an immunofluorescence study. J Comp Neurol 181:17-39.

Nicholas AP; Hökfelt T, Pieribone VA (1996) The distribution and significance of CNS adrenoceptors examined with in situ hybridization. Trends Pharmacol Sci 17:245-255.

Nicoll RA, Malenka RC, Kauer AJ (1990) Functional comparison of neurotransmitter receptor subtypes in mammalian central nervous system. Physiol Rev 70:513-565.

Pitler TA, Alger BE (1992) Cholinergic excitation of GABAergic interneurons in the rat hippocampal slice. J Physiol (Lond) 450:127-142.

Randle JCR, Bourque CW, Renaud LP (1986) $\alpha_{1}$-Adrenergic receptor activation depolarizes rat supraoptic neurosecretory neurons in vitro. Am J Physiol 251:R569-R574.

Roerig B, Katz LC (1997) Modulation of intrinsic circuits by serotonin $5-\mathrm{HT}_{3}$ receptors in developing ferret visual cortex. J Neurosci 17:8324-8338.

Sakaguchi T, Nakamura S (1987) The mode of projections of single locus coeruleus neurons to the cerebral cortex in rats. Neuroscience 20:221-230.

Salin PA, Prince DA (1996) Spontaneous GABA $_{\mathrm{A}}$ receptor-mediated inhibitory currents in adult rat somatosensory cortex. J Neurophysiol 75:1573-1588.

Scanziani M, Gähwiler BH, Thompson SM (1993) Presynaptic inhibition of excitatory synaptic transmission mediated by alpha adrenergic receptors in area CA3 of the rat hippocampus in vitro. J Neurosci 13:5393-5401.
Séguéla P, Watkins KC, Geffard M, Descarries L (1990) Noradrenaline axon terminals in adult rat neocortex: an immunocytochemical analysis in serial thin sections. Neuroscience 35:249-264.

Somogyi P, Hodgson AJ, Smith AD, Nunzi MG, Gorio A, Wu J-Y (1984) Different populations of GABAergic neurons in the visual cortex and hippocampus of cat contain somatostatin- or cholecystokininimmunoreactive material. J Neurosci 4:2590-2603.

Umbriaco D, Watkins KC, Descarries L, Cozzari C, Hartman BK (1994) Ultrastructural and morphometric features of the acetylcholine innervation in adult rat parietal cortex: an electron microscopic study in serial sections. J Comp Neurol 348:351-373.

Van Bockstaele EJ, Colago EE, Pickel VM (1996) Enkephalin terminals form inhibitory-type synapses on neurons in the rat nucleus locus coeruleus that project to the medial prefrontal cortex. Neuroscience $71: 429-442$.

Videen TO, Daw NW, Rader RK (1984) The effect of norepinephrine on visual cortical neurons in kittens and adult cats. J Neurosci 4:1607-1617.

Wang Z, McCormick DA (1993) Control of firing mode of corticotectal and corticopontine layer $\mathrm{V}$ burst-generating neurons by norepinephrine, acetylcholine, and 1S,3R-ACPD. J Neurosci 13:2199-2216.

Warren RA, Dykes RW (1996) Transient and long-lasting effects of iontophoretically administered norepinephrine on somatosensory cortical neurons in halothane-anesthetized cats. Can J Physiol Pharmacol 74:38-57.

Waterhouse BD, Woodward DJ (1980) Interaction of norepinephrine with cerebrocortical activity evoked by stimulation of somatosensory afferent pathways in the rat. Exp Neurol 67:11-34. 